\title{
From Tyrian Purple to Kinase Modulators: Naturally Halogenated Indirubins and Synthetic Analogues
}

Authors

Affiliation
Konstantina Vougogiannopoulou, Alexios-Leandros Skaltsounis

Department of Pharmacognosy and Natural Product Chemistry, Faculty of Pharmacy, National and Kapodistrian University of Athens, Athens, Greece

Key words
Indirubin
indigo
Tyrian purple
Hexaplex trunculus
Bolinus brandaris
Muricidae
protein kinases
CDKs
GSK-3 $\beta$
stem cells

received April 13, 2012

revised June 16, 2012

accepted July 24,2012

\section{Bibliography}

DOI http://dx.doi.org/

10.1055/s-0032-1315261

Published online Sept. 12, 2012

Planta Med 2012; 78 :

1515-1528 @ Georg Thieme

Verlag KG Stuttgart · New York .

ISSN 0032-0943

\section{Correspondence}

Prof. Alexios-Leandros

Skaltsounis

Department of Pharmacognosy and Natural Product Chemistry

Faculty of Pharmacy

National and Kapodistrian

University of Athens

Panepistimiopolis Zografou

15771 Athens

Greece

Phone: + 302107274598

Fax: + 302107274594

skaltsounis@pharm.uoa.gr

\section{Abstract}

$\nabla$

Indirubins represent a small category of compounds with significant pharmacological activity focusing on the inhibition of protein kinases. A series of derivatives has been developed during the last 15 years aiming the investigation and amelioration of the indirubin scaffold in terms of activity, selectivity, and drug-likeness. The current article focuses on the naturally brominated indirubins present in the famous historic dye of Tyrian purple, attempting to gather all available literature regarding biosynthesis, isolation, and synthesis of related analogues. Halogenated indirubins are by far one of the most important subcate-

\section{Introduction - Tyrian purple}

$\nabla$

Indirubin (1), indigo (2), and isoindigo (3) are the core representatives of a rather small category of bisindole alkaloids referred to as indigoids ( Fig. 1). Their fascinating history begins before even their exact chemical structure was elucidated. These compounds are the colored constituents of the natural dyes indigo and the famous molluscan Tyrian purple, used throughout the centuries for textile dying and so providing a significant commercial benefit to communities which produced it.

Indigo dye was used as a blue natural dye from the Bronze Age ( 7000). It has been established that the treatment of indigo bearing plants (Brassicaceae, Polygonaceae, Fabaceae) for the production of the blue dye was a common practice in the past, almost worldwide. In Europe, indigo was predominantly produced from the woad of Isatis tinctoria (Brassicaceae) [1]. According to Pliny the Elder, the inhabitants of Britain used to paint their faces with a blue dye (indigo) in order to appear more intimidating to the enemy. The cultivation and process of woad and the trading of indigo gories of indirubins, with its main representatives 6-bromoindirubin (6BI) and 6-bromoindirubin3'-oxime (6BIO) possessing an increased selectivity against GSK-3. This review attempts to summarize concisely structure/activity relationships among closely related halogenated analogues in terms of protein kinase inhibition and selectivity, while it also focuses on the various biological applications arising from the interactions of halogenated indirubins with molecular targets. Those include effects of halogenated indirubins on stem cells, cardiac, renal, and pancreatic cells, on leukemia and solid tumors, and on neurodegeneration.

were extremely vital economical elements of the renaissance commerce. The main production and trade centers were Albi/Toulouse in France, Somerset in Great Britain, Thüringen in Germany, and Florence in Italy.

In India, Pakistan, South America, and Africa, Indigofera tinctoria (Fabaceae) was cultivated and processed for the production of indigo dye [2] while the Mayas have combined indigo and natural clays to prepare the pigment Maya blue [3]. In China, Korea, and Japan, Polygonum tinctorium (Polygonaceae) was used for the preparation of indigo dye, although the species was considered poor in terms of indigo content [4].

While indigo was considered to be a «dye of the poor», Tyrian purple was used widely to declare prestige and social status. Its extensive use from the Persians dates back to $560 \mathrm{BC}$, and up to date it is one of the oldest ancient pigments found on objects of cultural significance. Roman and Byzantine emperors used it to color ceremonial robes while a variation of Tyrian purple [5], the blue Tekhelet is mentioned in the Jewish bible as the dye used in the clothes of the High Priest [6]. The oldest application of molluscan purple dye dates 


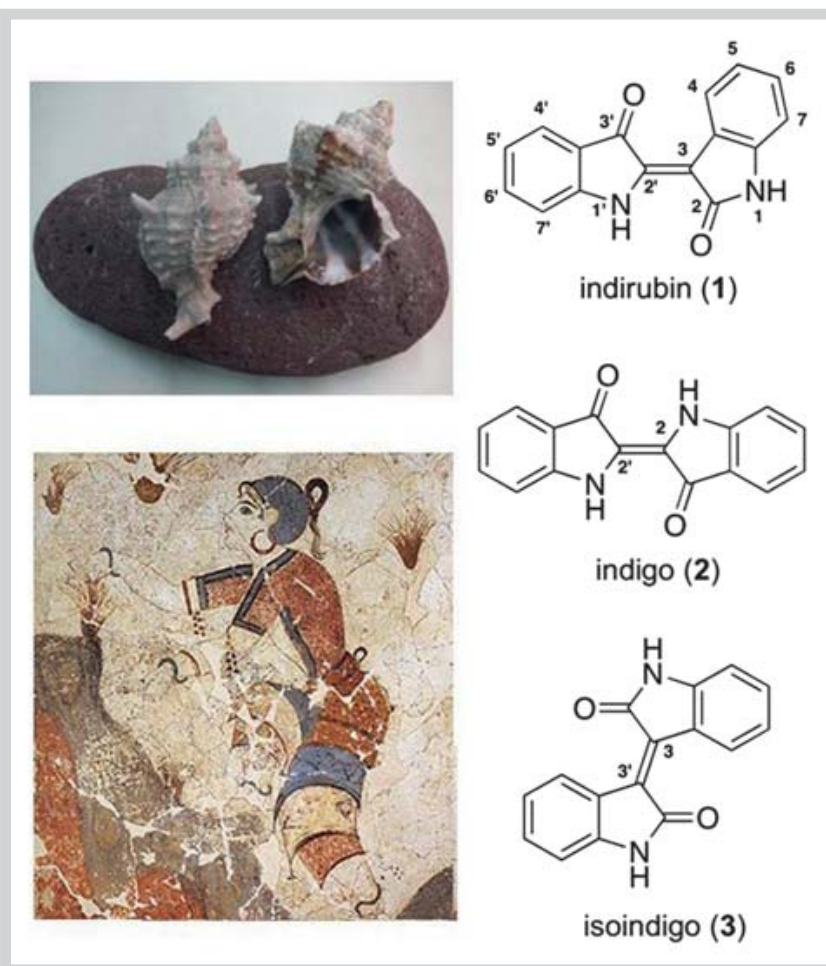

Fig. 1 Structures of indirubin (1), indigo (2), and isoindigo (3). The Tyrian purple producing mollusk Hexaplex trunculus (Muricidae) and details of the fresco entitled "The Saffron Gatherers" located in the archaeological site of Akrotiri, Thera, Greece.

back to the Late Bronze Age, as proven by the analysis of purple dyestuff found on the wall paintings at the archaeological site of Akrotiri, Thera, Greece ( Fig. 1) [7]. Recently, in Church Madeleine, Manas, France, Tyrian purple was identified on the mural paintings, the pigment being probably transported to France from the Mediterranean basin after the Third Crusade. This act is indicative of how much appreciated this pigment was throughout the centuries [8].

The highly prized purple reddish dye was obtained in the Mediterranean basin mainly from the gastropods Hexaplex trunculus and Bolinus brandaris (Muricidae) and considered to be an important trade good in Crete, Phoenicia, Greece, and Rome. On the coasts of North Atlantic, the purple dye was produced from Nucella lapillus (dog whelk) [9] while on the Pacific coasts of Latin America, other species were used such as Plicopurpura pansa [10].

In contrast with indigo dyes, the major constituents of molluscan purple dyes are brominated indigoids. The purple color of Tyrian purple is attributed both to the presence of indirubin derivatives giving a red hue and also to the fact that brominated indigos in solid state are in fact purple instead of blue. The variety of indigoids present and therefore the vast achievable color palette, as well as the limited quantity of mollusks available for processing, were the main reasons due to which Tyrian purple was more appreciated than the indigo dye.

Nowadays, the use of natural dyes is very limited due to their replacement with cheaper synthetic dyes. Nevertheless, indigoids and especially indirubins have come to the forefront due to the vast range of biological activities, which in many cases have their origin in traditional medicine. Chronic myeloid leukemia (CML) has been treated in the traditional Chinese medicine with the recipe Danggui Longhui Wan, a mixture of 11 herbal medicines. The active ingredient was found to be a dark blue powder, Qing Dai, prepared from the leaves of indigo producing plants. Eventually, the antileukemic activity was attributed to indirubin, which was detected in the mixture of Danggui Longhui Wan as a minor constituent [11].

Since then, indirubin and its halogenated analogues have exerted a vast range of biological effects in stem cells [12], cardiac, renal, and pancreatic cells. In addition, brominated indirubins have been utilized as tools for the exploration of neurodegeneration, cancer, and as potential therapeutic agents for parasitic diseases. In most of the cases, all of the above effects can be associated with the interaction of indirubins with important molecular targets such as members of the family of protein kinases (GSK-3 [13], CDKs [14], and Aurora kinases [15]) and the aryl hydrocarbon receptor $[16,17]$, placing them among the most promising naturederived drug candidates [18].

\section{Chemistry of Halogenated Indirubin Analogues \\ $\nabla$}

\section{Natural sources}

The name "indirubin" was first introduced in 1855 by Edward Schunck [19] to describe a red coloring ingredient present in indigo producing plants. Extensive studies performed thereafter, have proven that indirubin is present in diverse natural sources such as the indigo producing plants of Isatis spp. [20], Indigofera spp., and Polygonum spp., recombinant bacteria, [21] mammalian - including human - urine [22], and Tyrian purple producing marine mollusks [23] (๑ Fig. 2).

The pigments present in the plant-derived indigo dye are formed with the dimerization of indole glucosidic precursors, under the treatment of the plant for the production of the dye [24]. The main precursors involve indican (4), isatan A (5), and isatan B (6) [25], while their presence prior to the production of the dye is largely dependent on the post-harvest treatment of the plant [24]. Indirubin has been successfully isolated from the leaves of Isatis with the use of "green" techniques as supercritical fluid extraction (SFE) [26].

On the other hand, indirubins of molluscan origin are present in the purple pigment of Tyrian purple which is produced by organisms of the Muricidae family. The simultaneous presence of nonbrominated and brominated indigoids in Tyrian purple was reported for the first time in 1909 with the isolation of 6,6'-dibromoindigo (7) from Hexaplex trunculus [27]. The predominant indigoid ingredient of the dye depends greatly on the species used for the production as well as the conditions under which it was produced. Among the most commonly used mollusks for the production of the dye, Hexaplex trunculus was found to possess the greatest variety of brominated indigoids: indigo, 6-bromoindigo (8), 6,6'-dibromoindigo (7), as well as indirubin (2), 6bromoindirubin (9, 6BI), 6,6'-dibromoindirubin (10), and 6'-bromoindirubin (11) are all present in the DMF extract thereof [28]. Interestingly, indigoids are not present in the mollusk itself rather than being synthesized in the procedure of dye production, which involves alkaline treatment of the mollusk and exposure to sunlight. This process was later on partially elucidated with the isolation from Dicathais orbita of the colorless ultimate precursor tyrindoxyl sulfate (12) $[29,30]$ as well as several intermediates from this species and other Muricidae such as tyrindoxyl (14), tyrindoleninone (15), and tyriverdin (16) [31-33]. In $H$. 


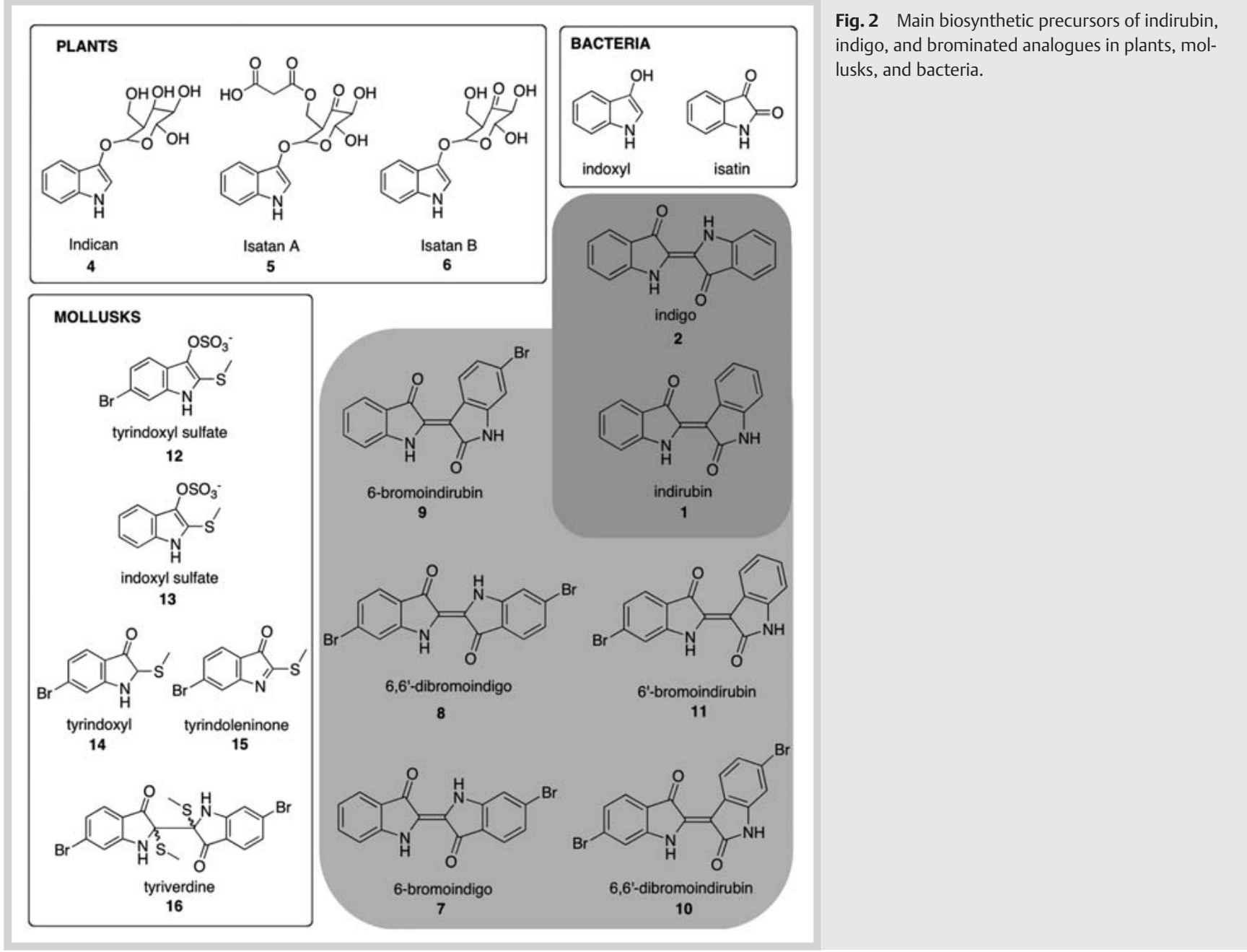

trunculus, which for the moment exhibits the greatest variety of indigoids, indoxyl sulfate (13) has also been proposed as another ultimate precursor, [34] a fact that is reflected upon its variety of non-, mono- and dibrominated indigoids. Nowadays, we can attribute the formation of the marine indigoids to a series of oxidative, photochemical, enzymatic transformations and dimerizations, although a concise concept of their genesis is yet to be clarified. Recent advances suggest that their origin is likely to be sexspecific and related to reproduction [35], as purple pigmentation has been detected in the egg masses of several gastropods [36, 37].

\section{Bioguided isolation of brominated indirubins and precursors}

The general interest in indirubin scaffolds due to their use in traditional medicine and their identification as kinase inhibitors led to the investigation of brominated indirubins as bioactive agents. The isolation of natural mono- and dibrominated indirubins, along with indirubin, has been performed from the whole body mass of $H$. trunculus after exposure to light and oxygen, lyophilization, and extraction with dichloromethane. Removal by precipitation of the insoluble indigo derivatives affords an indirubinenriched dichloromethane extract $(0.25 \mathrm{mg}$ of indirubin content in $1 \mathrm{~kg}$ of dried mollusks), of which with the aid of MPLC fractionation four fractions corresponding to indirubin and the aforementioned derivatives can be obtained [38].
After screening of the fractions representing indirubin and the natural 6-brominated analogues on a set of 3 kinases (CDK1/cyclinB, CDK5/p35, and GSK-3 $\beta$ ), 6-bromoindirubin $(9,6 \mathrm{BI})$ was identified as a potent and selective GSK-3 inhibitor [39]. It was the first time $\mathbf{6 B I}$ was isolated from a natural source as a minor indirubin constituent of Tyrian purple, although it has been detected numerous times in Muricidae extracts and artifacts dyed with Tyrian purple via chromatographic analytical techniques $[40,41]$.

On the other hand, the interest in indirubin percursors focuses not on kinase inhibition but strong antimicrobial activity. Under this scope, organic solvent extracts of the egg masses of $D$. orbita were examined for their bacteriostatic activity against human and marine pathogens (E. coli, S. aureus, P. aeruginosa). Bioguided isolation of the precursors led to the isolation and identification of tyriverdin (16) as a strong antimicrobial agent at a concentration of $1-0.5 \mu \mathrm{g} / \mathrm{ml}$ [42]. Moreover, tyrindoleninone (15) and its oxidation product 6-bromoisatin (17) are identified as anticancer agents [43] while extracts containing indole Tyrian purple precursors have a potential chemopreventive role in colorectal cancer [44]. 
Total synthesis of halogenated indirubins and related analogues

Total synthesis of indirubin was performed for the first time in 1881 by A. Baeyer [45], a few years after its isolation from indigo dye. The original method was based on the reaction of indoxyl with isatin under alkaline conditions, while during the 20th century the procedure was modified by the use of the more stable acetoxyindole [46]. Even though many analogues of indirubin have been reported, the basic synthetic preparation has been to a large extent conserved. Synthesis of $\mathbf{6 B I}$ [47] is based on the combination under mild alkaline conditions of acetoxyindole with 6-bromoisatin (17), the latter being easily prepared from 6bromoaniline (18) through the 2-step Sandmeyer synthesis [48]. First, the aniline is converted to the corresponding isonitrosoacetanilide (19) under treatment with chloral hydrate and hydroxylamine, while in the second step the acetanilide undergoes cyclization in concentrated sulfuric acid resulting in the formation of the isomeric 6-bromoisatin and 4-bromoisatin, which are separated under fractional precipitation in an acidic environment. Shifting of the 6BI bromine atom to positions 5 and 7, results in the formation of 5-bromoindirubin $(\mathbf{2 0}, \mathbf{5 B I})$ and 7-bromoindirubin $(21,7 \mathrm{BI})$, synthesized similarly to $\mathbf{6 B I}$ from 5 -bromoisatin and 7-bromoisatin, respectively. Five and 7 bromosubstituted indirubins are not naturally derived in terms of the bromine position, as no report of them as natural products is present in current literature.

A large series of indirubin analogues bearing halogens or simple substituents on the benzene rings has been achieved with the aforementioned procedure ( $\bigcirc$ Fig. 3 ), starting from the corresponding isatins and acetoxyindoles [49-51]. Those analogues involve methoxylated indirubins [52], 5,7-bisubstituted aniline analogues [53], 5-nitro analogues [54,55], 5-carbamates bearing unsaturated and aromatic side chains [56], and 5,5' bisubstituted analogues with halogenated and hydroxylated substituents [57, 58].

One of the most promising modifications performed on the indirubin core, so far concerning the modulation of activity and solubility properties, is the conversion of the $3^{\prime}$ carbonyl group into an oxime group ( $\odot$ Fig. 3). Thus, in the case of indirubin and the brominated $\mathbf{5 B I}, \mathbf{6 B I}$, and $\mathbf{7 B I}$, treatment with hydroxylamine hydrochloride in pyridine results in the formation of the corresponding oximes, namely indirubin-3'-oxime (22, 10), 5-bromoindirubin-3'-oxime (23, 5BIO), 6-bromoindirubin-3'-oxime (24, 6BIO), and 7-bromoindirubin-3'-oxime (25, 7BIO), molecules with a vast range of biological activity and in the case of 6BIO, enhanced potency and selectivity towards GSK-3 $\beta$ [51].

Several analogues of halogenated indirubins have been developed aiming the improvement of biological properties on the one hand and enhanced drugability on the other, given the fact that simple indirubin analogues are characterized by low solubility. $\log D$ values of $\mathbf{6 B I O}$ (2.59) [59], 5BI, and indirubin (3.7 and 2.5 , respectively) [61] reflect the low hydrophilicity of simple indirubins despite the presence of an oxime group. A series of $\mathbf{6 B I O}$ analogues possessing amino-aliphatic chains on the $3^{\prime}$ oxime group exerted selectivity against GSK-3 $\beta$ and also a more favorable solubility in water with $\log D$ values varying from 1.90 (36) to -0.87 for the simple piperazine analogue (33) ( 0 Fig. 4, products 27-37) $[59,60]$. The introduction of those hydrophilic chains is achieved through the intermediate formation of the 3'-oxime ether bearing a terminal bromine atom (26), which is afterwards substituted with commercially available secondary amines. Similarly, 7BIO analogues of the same type have been synthesized bearing varying long hydrophilic chain substituents on position $3^{\prime}[61]$.

Under the same perspective of enhancing the solubility of bioactive indirubins, sugar moieties have been introduced to the basic core. Retaining the synthetic methodology of dimerization, sugar moieties have been incorporated in positions 1 and $1^{\prime}$, originating from glycosylated isatins and indoxyls, respectively $[62,63]$. Finally, one of the most radical interventions performed so far to indirubin has been the introduction of a heterocyclic nitrogen atom to the benzene ring originating from isatin. This attempt to simulate the presence of a bromine atom in position 7 resulted in the synthesis of 7-azaindirubin, an isostere of the natural indirubin with antiproliferative properties $[64,65]$.

For the class of 5-brominated indirubins, more soluble 5-substituted analogues have been developed simulating the brominated core, with the main representatives indirubin-5-sulfonate (38, E622) and 5-carboxyindirubin (39) being the lead compounds in a series of 5-substituted analogues [60]. On this basis, compounds bearing polar hydroxylated chains on position 3', basic sulfonamide ( $\odot$ Fig. 4, products $40-44$ ), and carboxamide ( $O$ Fig. 4, products 45-55) groups on position 5 have been developed with remarkable water solubility $(\log D-2.1$ for E622) and significant cytotoxicity [66]. Finally, a series of 5-substituted nonplanar indirubins has been developed via the transformation of the 3 ' carbonyl group into a quaternary carbon ( $\odot$ Fig. 4, products 56-57), a change very effective in terms of solubility [60].

\section{Biological Properties of Halogenated Indirubins and Analogues \\ $\nabla$}

\section{Protein kinase inhibition}

Protein kinases (PKs) consist in a vast group of enzymes catalyzing the reversible phosphorylation of protein substrates [67]. Due to this vital function, they have been found to participate in most of the signal transduction processes in the eukaryotic cell [68], while their deregulation has been established in a number of diseases such as cancer [69], neurodegeneration, and protozoan infections [70]. Indirubins are considered ATP-competitive PK inhibitors, while screening of 85 kinases of the ProQinase "selectivity panel" revealed a selectivity trend for IO, 5BIO, 6BIO, and 7BIO [71].

A very important group of the human kinome (as the sum of the kinases expressed from humans is referred [72]) is represented by the CDKs (cyclin dependent kinases). They are serine/threonine kinases which are to a large extent conserved, and require the binding with a cofactor for their activation (e.g., cyclins). They play a vital role in the cell cycle by controlling its progression through a succession of activation and deactivation events [73, 74]. Most of the CDKs have been associated to various forms of cancer, thus making the discovery of new and specific inhibitors an intriguing target during the past years $[75,76]$. Indirubins in general are considered to be inhibitors of CDK1, CDK2, and CDK5 [77], the former being of uttermost importance to the general cell cycle progression while the latter is expressed mostly in neurons [78].

GSK-3 (glycogen synthase kinase), although originally discovered for its implication in diabetes through phosphorylation of glycogen synthase [79], has been brought to attention due to its abundance in brain cells and neurons and its ability to abnormally phosphorylate tau protein in the Alzheimer's disease (AD) pathway [80]. Tau's aggregation is responsible for the formation of the 


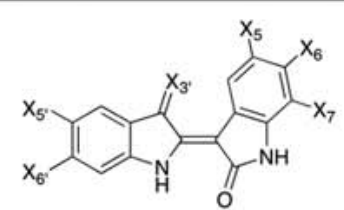

\begin{tabular}{|c|c|c|c|c|c|c|c|c|c|c|c|c|c|c|}
\hline & $x_{5}$ & $X_{6}$ & $X_{7}$ & $X_{3}$ & $x_{5}$ & $X_{6}$ & $\begin{array}{c}\text { CDK1 } \\
\text { cyclin B }\end{array}$ & $\begin{array}{l}\text { CDK2 } \\
\text { cyclin E }\end{array}$ & $\begin{array}{c}\text { CDK5 } \\
\text { p25 }\end{array}$ & $\begin{array}{l}\text { GSK- } \\
3 \alpha / \beta\end{array}$ & Aur A & Aur B & Aur C & FLT3 \\
\hline 1 & $\mathrm{H}$ & $\mathrm{H}$ & $\mathrm{H}$ & 0 & $\mathrm{H}$ & $\mathrm{H}$ & & & & & - & - & - & - \\
\hline $22(10)$ & $\mathrm{H}$ & $\mathrm{H}$ & $\mathrm{H}$ & $\mathrm{NOH}$ & $\mathrm{H}$ & $\mathrm{H}$ & & & & & & & & \\
\hline \multicolumn{15}{|c|}{ 5-substituted } \\
\hline $20(5 \mathrm{BI})$ & $\mathrm{Br}$ & $\mathrm{H}$ & $\mathrm{H}$ & 0 & $\mathrm{H}$ & $\mathrm{H}$ & & & & & - & - & - & - \\
\hline 23 (5BIO) & $\mathrm{Br}$ & $\mathrm{H}$ & $\mathrm{H}$ & $\mathrm{NOH}$ & $\mathrm{H}$ & $\mathrm{H}$ & & & & & 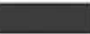 & & & \\
\hline $58(5 \mathrm{CII})$ & $\mathrm{Cl}$ & $\mathrm{H}$ & $\mathrm{H}$ & 0 & $\mathrm{H}$ & $\mathrm{H}$ & & & - & & - & - & - & \\
\hline $59(5 \mathrm{CllO})$ & $\mathrm{Cl}$ & $\mathrm{H}$ & $\mathrm{H}$ & $\mathrm{NOH}$ & $\mathrm{H}$ & $\mathrm{H}$ & - & - & - & - & - & - & - & \\
\hline $60(5 \mathrm{FI})$ & $F$ & $\mathrm{H}$ & $\mathrm{H}$ & 0 & $\mathrm{H}$ & $\mathrm{H}$ & & - & & & - & - & - & \\
\hline $61(5 \mathrm{FIO})$ & $\mathrm{F}$ & $\mathrm{H}$ & $\mathrm{H}$ & $\mathrm{NOH}$ & $\mathrm{H}$ & $\mathrm{H}$ & & - & & & - & - & - & \\
\hline $62(511)$ & 1 & $\mathrm{H}$ & $\mathrm{H}$ & 0 & $\mathrm{H}$ & $\mathrm{H}$ & & - & & & - & - & - & \\
\hline $63(5110)$ & 1 & $\mathrm{H}$ & $\mathrm{H}$ & $\mathrm{NOH}$ & $\mathrm{H}$ & $\mathrm{H}$ & & - & & IIIIII & - & - & - & \\
\hline \multicolumn{15}{|c|}{ 6-substituted } \\
\hline $9(6 \mathrm{BI})$ & $\mathrm{H}$ & $\mathrm{Br}$ & $\mathrm{H}$ & 0 & $\mathrm{H}$ & $\mathrm{H}$ & & - & & & - & - & - & - \\
\hline 24 (6BIO) & $\mathrm{H}$ & $\mathrm{Br}$ & $\mathrm{H}$ & $\mathrm{NOH}$ & $\mathrm{H}$ & $\mathrm{H}$ & & 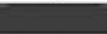 & & & 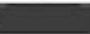 & & & \\
\hline 64 & $\mathrm{H}$ & $\mathrm{Br}$ & $\mathrm{H}$ & NOAC & $\mathrm{H}$ & $\mathrm{H}$ & & - & & & - & - & - & $=$ \\
\hline 65 (6CII) & $\mathrm{H}$ & $\mathrm{Cl}$ & $\mathrm{H}$ & 0 & $\mathrm{H}$ & $\mathrm{H}$ & & - & & & - & - & - & - \\
\hline 66 (6ClIO) & $\mathrm{H}$ & $\mathrm{Cl}$ & $\mathrm{H}$ & $\mathrm{NOH}$ & $\mathrm{H}$ & $\mathrm{H}$ & & - & & & $\cdot$ & - & - & - \\
\hline $67(6 \mathrm{FI})$ & $\mathrm{H}$ & $\mathrm{F}$ & $\mathrm{H}$ & 0 & $\mathrm{H}$ & $\mathrm{H}$ & & - & & & - & - & - & - \\
\hline 68 (6FIO) & $\mathrm{H}$ & $\mathrm{F}$ & $\mathrm{H}$ & $\mathrm{NOH}$ & $\mathrm{H}$ & $\mathrm{H}$ & & $\cdot$ & & & - & - & - & - \\
\hline $69(611)$ & $\mathrm{H}$ & 1 & $\mathrm{H}$ & 0 & $\mathrm{H}$ & $\mathrm{H}$ & & - & & & - & - & - & - \\
\hline $70(6110)$ & $\mathrm{H}$ & 1 & $\mathrm{H}$ & $\mathrm{NOH}$ & $\mathrm{H}$ & $\mathrm{H}$ & & - & & & - & - & - & - \\
\hline \multicolumn{15}{|c|}{ 7-substituted } \\
\hline $21(7 \mathrm{BI})$ & $\mathrm{H}$ & $\mathrm{H}$ & $\mathrm{Br}$ & 0 & $\mathrm{H}$ & $\mathrm{H}$ & & - & & & & & & - \\
\hline 25 (7BIO) & $\mathrm{H}$ & $\mathrm{H}$ & $\mathrm{Br}$ & $\mathrm{NOH}$ & $\mathrm{H}$ & $\mathrm{H}$ & & & & & & & & \\
\hline 71 (7CII) & $\mathrm{H}$ & $\mathrm{H}$ & $\mathrm{Cl}$ & 0 & $\mathrm{H}$ & $\mathrm{H}$ & & - & & & & & & - \\
\hline $72(7 \mathrm{CIIO})$ & $\mathrm{H}$ & $\mathrm{H}$ & $\mathrm{Cl}$ & $\mathrm{NOH}$ & $\mathrm{H}$ & $\mathrm{H}$ & & - & & & & - & 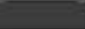 & - \\
\hline $73(7 \mathrm{FI})$ & $\mathrm{H}$ & $\mathrm{H}$ & $\mathrm{F}$ & 0 & $\mathrm{H}$ & $\mathrm{H}$ & & - & & & & - & 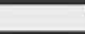 & - \\
\hline 74 (7FIO) & $\mathrm{H}$ & $\mathrm{H}$ & $\mathrm{F}$ & $\mathrm{NOH}$ & $\mathrm{H}$ & $\mathrm{H}$ & & $\cdot$ & & & - & - & - & - \\
\hline 75 (7II) & $\mathrm{H}$ & $\mathrm{H}$ & 1 & 0 & $\mathrm{H}$ & $\mathrm{H}$ & & - & & & - & - & - & - \\
\hline $76(7110)$ & $\mathrm{H}$ & $\mathrm{H}$ & 1 & $\mathrm{NOH}$ & $\mathrm{H}$ & $\mathrm{H}$ & & - & & & & & - & - \\
\hline \multicolumn{15}{|c|}{ 5,6-bisubstituted } \\
\hline 77 & $\mathrm{CH}_{3}$ & $\mathrm{Br}$ & $\mathrm{H}$ & 0 & $\mathrm{H}$ & $\mathrm{H}$ & & - & & & - & - & - & - \\
\hline 78 (5Me6BIO) & $\mathrm{CH}_{3}$ & $\mathrm{Br}$ & $\mathrm{H}$ & $\mathrm{NOH}$ & $\mathrm{H}$ & $\mathrm{H}$ & & - & & WIIIIs & - & - & $\cdot$ & - \\
\hline 79 & $\mathrm{NO}_{2}$ & $\mathrm{Br}$ & $\mathrm{H}$ & 0 & $\mathrm{H}$ & $\mathrm{H}$ & & - & & & - & - & - & - \\
\hline 80 & $\mathrm{NO}_{2}$ & $\mathrm{Br}$ & $\mathrm{H}$ & $\mathrm{NOH}$ & $\mathrm{H}$ & $\mathrm{H}$ & & - & & Us & - & - & - & - \\
\hline 81 (5A6BI) & $\mathrm{NH}_{2}$ & $\mathrm{Br}$ & $\mathrm{H}$ & 0 & $\mathrm{H}$ & $\mathrm{H}$ & - & - & & & - & - & - & - \\
\hline 82 & $\mathrm{Cl}$ & $\mathrm{Cl}$ & $\mathrm{H}$ & 0 & $\mathrm{H}$ & $\mathrm{H}$ & & - & & & - & - & - & - \\
\hline 83 & $\mathrm{Cl}$ & $\mathrm{Cl}$ & $\mathrm{H}$ & $\mathrm{NOH}$ & $\mathrm{H}$ & $\mathrm{H}$ & & - & & IIIIII & - & - & - & - \\
\hline \multicolumn{15}{|c|}{ 5,7-bisubstituted } \\
\hline 84 & $\mathrm{NO}_{2}$ & $\mathrm{H}$ & $\mathrm{Br}$ & 0 & $\mathrm{H}$ & $\mathrm{H}$ & & - & & & - & - & - & - \\
\hline 85 & $\mathrm{NO}_{2}$ & $\mathrm{H}$ & $\mathrm{Br}$ & $\mathrm{NOH}$ & $\mathrm{H}$ & $\mathrm{H}$ & & - & & & $\cdot$ & - & - & - \\
\hline 86 & $\mathrm{Cl}$ & $\mathrm{H}$ & $\mathrm{CH}_{3}$ & $\mathrm{NOH}$ & $\mathrm{H}$ & $\mathrm{H}$ & - & - & - & - & - & - & - & 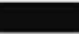 \\
\hline \multicolumn{15}{|c|}{6,6 -bisubstituted } \\
\hline 87 & $\mathrm{H}$ & $\mathrm{Br}$ & $\mathrm{H}$ & 0 & $\mathrm{H}$ & $\mathrm{Br}$ & & - & & & $\cdot$ & - & - & - \\
\hline 88 & $\mathrm{H}$ & $\mathrm{Br}$ & $\mathrm{H}$ & $\mathrm{NOH}$ & $\mathrm{H}$ & $\mathrm{Br}$ & & - & & & - & - & - & - \\
\hline \multicolumn{15}{|c|}{ 5,5-bisubstituted } \\
\hline 89 & $\mathrm{Br}$ & $\mathrm{H}$ & $\mathrm{H}$ & 0 & $\mathrm{Br}$ & $\mathrm{H}$ & & - & & & - & - & - & - \\
\hline 90 & $\mathrm{Br}$ & $\mathrm{H}$ & $\mathrm{H}$ & $\mathrm{NOH}$ & $\mathrm{Br}$ & $\mathrm{H}$ & & - & & & - & - & - & - \\
\hline 91 & $\mathrm{Cl}$ & $\mathrm{H}$ & $\mathrm{H}$ & $\mathrm{NOH}$ & $\mathrm{OH}$ & $\mathrm{H}$ & - & TIIIs & - & - & - & - & - & - \\
\hline 92 & $\mathrm{Cl}$ & $\mathrm{H}$ & $\mathrm{H}$ & $\mathrm{NOH}$ & $\mathrm{Cl}$ & $\mathrm{H}$ & - & & - & - & - & - & - & - \\
\hline 93 & $\mathrm{Cl}$ & $\mathrm{H}$ & $\mathrm{H}$ & $\mathrm{NOH}$ & $\mathrm{F}$ & $\mathrm{H}$ & - & & - & - & - & - & - & - \\
\hline 94 & $\mathrm{~F}$ & $\mathrm{H}$ & $\mathrm{H}$ & $\mathrm{NOH}$ & $\mathrm{OH}$ & $\mathrm{H}$ & - & UIIIII & - & - & - & - & - & - \\
\hline 95 & $F$ & $\mathrm{H}$ & $\mathrm{H}$ & $\mathrm{NOH}$ & $\mathrm{Cl}$ & $\mathrm{H}$ & - & & - & - & - & - & - & - \\
\hline 96 & $F$ & $\mathrm{H}$ & $\mathrm{H}$ & 0 & $F$ & $\mathrm{H}$ & & & & & - & - & - & - \\
\hline 97 & $F$ & $\mathrm{H}$ & $\mathrm{H}$ & $\mathrm{NOH}$ & $F$ & $\mathrm{H}$ & & TIII & & & - & - & - & - \\
\hline 98 & $F$ & $\mathrm{H}$ & $\mathrm{H}$ & $\mathrm{NOH}$ & $\mathrm{Br}$ & $\mathrm{H}$ & $=$ & - & & & - & - & - & - \\
\hline 99 & $F$ & $\mathrm{H}$ & $\mathrm{H}$ & $\mathrm{NOH}$ & $\mathrm{OCH}_{3}$ & $\mathrm{H}$ & - & $\mathbb{7}$ & - & - & $\cdot$ & - & - & - \\
\hline 100 & $\mathrm{NO}_{2}$ & $\mathrm{H}$ & $\mathrm{H}$ & $\mathrm{NOH}$ & $\mathrm{Cl}$ & $\mathrm{H}$ & & & - & - & - & - & - & - \\
\hline 101 & $\mathrm{OCF}_{3}$ & $\mathrm{H}$ & $\mathrm{H}$ & $\mathrm{NOH}$ & $\mathrm{Cl}$ & $\mathrm{H}$ & - & & - & - & - & - & - & - \\
\hline 102 & $\mathrm{NO}_{2}$ & $\mathrm{H}$ & $\mathrm{H}$ & $\mathrm{NOH}$ & $\mathrm{F}$ & $\mathrm{H}$ & - & IIIIII & - & - & - & - & - & - \\
\hline 103 & $\mathrm{OCF}_{3}$ & $\mathrm{H}$ & $\mathrm{H}$ & $\mathrm{NOH}$ & $F$ & $\mathrm{H}$ & - & & - & - & - & - & - & - \\
\hline 104 & $\mathrm{NO}_{2}$ & $\mathrm{H}$ & $\mathrm{H}$ & 0 & $\mathrm{Br}$ & $\mathrm{H}$ & & - & & & - & - & - & - \\
\hline 105 & $\mathrm{NO}_{2}$ & $\mathrm{H}$ & $\mathrm{H}$ & $\mathrm{NOH}$ & $\mathrm{Br}$ & $\mathrm{H}$ & & - & & & - & - & - & \\
\hline 106 & NHAC & $\mathrm{H}$ & $\mathrm{H}$ & 0 & $\mathrm{Br}$ & $\mathrm{H}$ & & - & & & - & - & - & - \\
\hline 107 & NHAC & $\mathrm{H}$ & $\mathrm{H}$ & $\mathrm{NOH}$ & $\mathrm{Br}$ & $\mathrm{H}$ & & - & & & - & - & - & - \\
\hline & & & & & & & & & & & & & & \\
\hline$>100 \mu \mathrm{k}$ & & & -100 & & & $10 \mu \mathrm{M}$ & & $0.1-1 \mu$ & & 0.01 & $0.1 \mu \mathrm{M}$ & & $<10 \mathrm{nl}$ & \\
\hline
\end{tabular}

Fig. 3 Simple substituted indirubin analogues bearing at least one halogen atom in their core and inhibitory activity against $C D K 1 /$ cyclin $B, C D K 2 /$ cyclin $\mathrm{E}, \mathrm{GSK}-3 \alpha / \beta, \mathrm{CDK} 5 / \mathrm{p} 25$, Auroras A, B, C, and FLT3. The colour scale repre- sents the range of activity indicated in the bottom. Data gathered from literature cited: [13-15, 17, 38, 51, 53, 54, 57, 58, 60, 61, 71, 162]. 


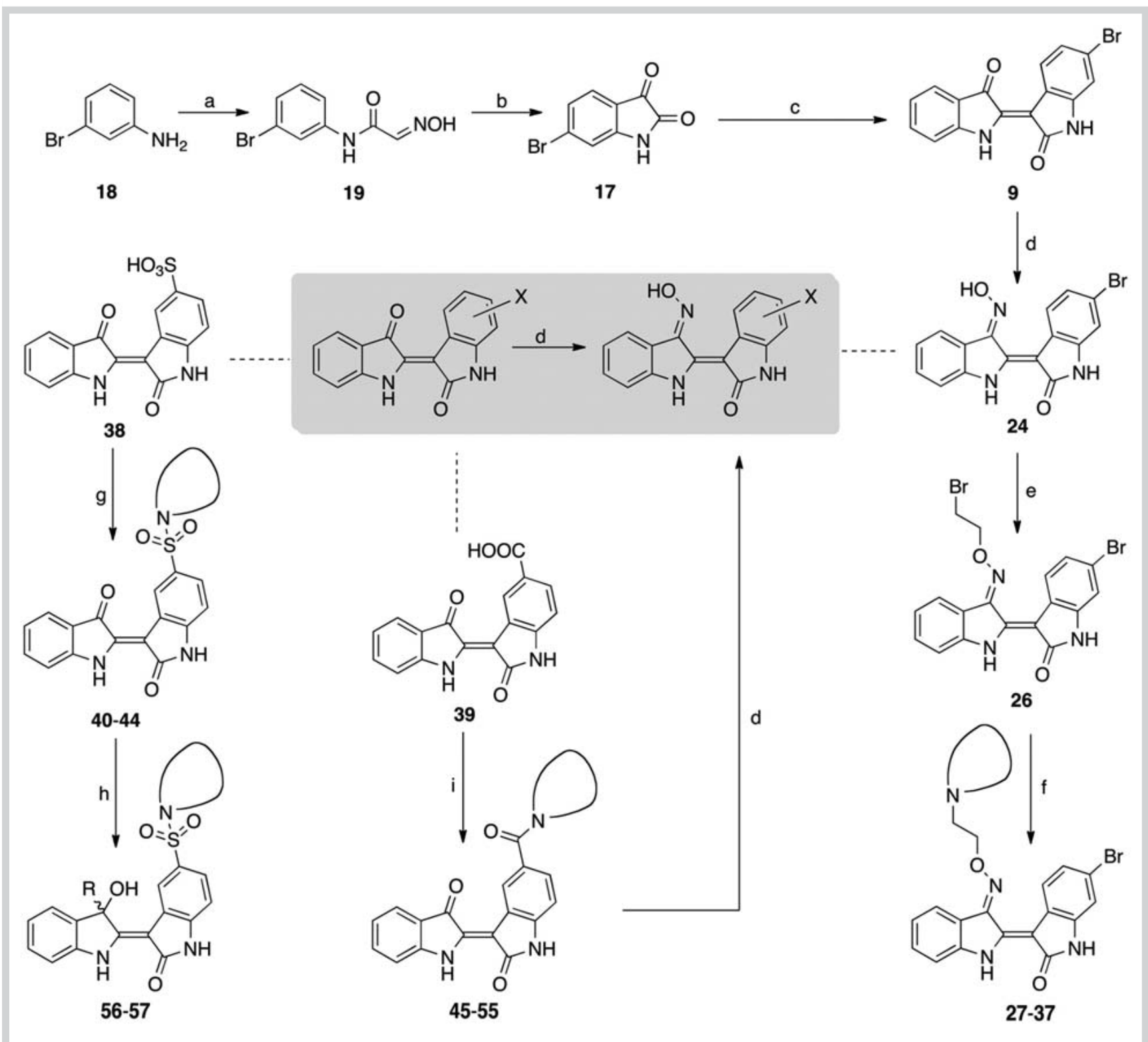

Fig. 4 Synthesis of 6-bromoindirubin and related substituted analogues. a Chloral Hydrate, $\mathrm{Na}_{2} \mathrm{SO}_{4}, \mathrm{NH}_{2} \mathrm{OH} \cdot \mathrm{HCl}, \mathrm{H}_{2} \mathrm{O}, \mathrm{H}^{+}$, b conc. $\mathrm{H}_{2} \mathrm{SO}_{4}$, c 3-acetoxyindole, $\mathrm{Na}_{2} \mathrm{CO}_{3}$, MeOH, d NH $\mathrm{NH}_{2} \mathrm{OH} \cdot \mathrm{HCl}$, py, reflux, e 1,2-dibromoethane, $\mathrm{Et}_{3} \mathrm{~N}$, DMF, RT [51]. For the preparation of the 6-Br amine analogues: $\mathbf{f} \mathrm{DMF}$, RT, secondary amines namely, dimethylamine (27), diethylamine (28), diethanolamine (29), 3-(methylamino)propane-1,2-diol (30), morpholine (31, 6-BIMYEO), pyrrolidine (32), piperazine (33), 1-methylpiperazine (34), 1-(2hydroxyethyl)piperazine (35), 1-(2-methoxyethyl)piperazine (36), 1-[2-(2hydroxyethoxy)ethyl]piperazine (37) [59]. For the preparation of the 5-sulfonamide analogues: $\mathbf{g} 2$ steps, $\mathrm{SOCl}_{2}, 80^{\circ} \mathrm{C}$ and DMAP (cat) with amines namely, dimethylamine (40), diethanolamine (41), 4-hydroxypiperidine (42), 4-dimethylaminopiperidine (43), $N, N, N^{\prime}$-trimethylethylenediamine (44) [60]. For the preparation of the 5-carboxamide analogues: $\mathbf{i}$ two steps, PFF-trifluoroacetate, DMAP, py, DMF, and DMAP, dioxane with the appropriate amine namely, piperazine (45), 1-methylpiperazine (46), ethanolamine (47), diethanolamine (48), N,N,N'-trimethylethylenediamine (49), N,N-dimethylethane-1,2-diamine (50), N,N-dimethyl-2-(4-methyl-1-piperazinyl)ethanamine (51), N,N-dimethyl-p-phenylenediamine (52), 3-aminopyridine (53), 4-(4-methyl-1-piperazinyl)aniline (54), 1-amino-1-deoxy-D-glucitol (55) [66]. For the preparation of the $3^{\prime}$-quaternary analogues: $\mathbf{h}$ Grigniard reactions in THF or py, $-20^{\circ} \mathrm{C}$, with alkyl-magnesium bromides, namely methylmagnesium bromide (56), allylmagnesium bromide (57) [60]. neurofibrillary tangles (NFTs) and the $\beta$-amyloid deposition observed in $\mathrm{AD}$ [81], while the role of GSK-3 in inflammation pathology of AD is under investigation [82].

The beta-isoform of GSK-3 (GSK-3 $\beta$ ) is found to be associated through various signaling pathways with mood disorders [83] and schizophrenia [84], osteoporosis [85] and cancer (Wnt signaling) [86], atherosclerosis, cardiac hypertrophy, hypertension [87], and signal transduction [88]. The natural 6BI and its semisynthetic analogue $6 \mathrm{BIO}$ are both potent and selective GSK-3 $\beta$ in- hibitors, a fact that gave rise to the commercialization of $6 \mathrm{BIO}$ under the name "BIO" and "GSK-3 inhibitor IX" [89] and the development of analogues with a vast range of biological applications.

Apart from the aforementioned kinases, indirubins also target the Aurora kinases [15], FLT3 (Fms-like tyrosine kinase 3) [58, 90], JAKs (Janus kinases) [91], and according to molecular modeling studies PDK1 (pyruvate dehydrogenase kinase 1), with specificity and potency depending on their chemical structure [92]. Fi- 
nally, it is worth mentioning that Leishmania sp. possesses protein kinases sharing certain homology to the mammalian ones (CRK3, LdGSK-3, and protozoan MAPKs), whose functional role in the life cycle of parasites can be even more important than in mammalian cells [70].

Interaction of indirubins with molecular targets such as the PKs causes the modulation of various physiological pathways. Inhibition of GSK-3 affects the progression of parental pathways Wnt and Hedgehog (Hh) [93]. Wnt is a signal transduction pathway controlling differentiation in the stage of embryonic development, stem cell fate in adults, neuronal development, and neuroprotection [94]. GSK-3 has been found to phosphorylate several components of Wnt, with $\beta$-catenin being one of the most important. In canonical Wnt signaling and in the absence of Wnt proteins, $\beta$-catenin is phosphorylated by GSK-3 and thus degraded by the proteasome. Inhibition of GSK-3 leads to $\beta$-catenin intracellular accumulation/stabilization and through a series of intracellular events triggers the transcription of target genes associated with apoptosis and cell proliferation [95]. Furthermore, inhibition of GSK-3 $\beta$ by indirubins, through its implication in the phosphatidylinositol 3-kinase Akt signaling pathways (PI3K/ Akt), is capable of modulating the expression of factors associated with hypoxia and ischemia [96] and apoptosis in serum-deprived conditions [97].

GSK-3 is also relevant to the effect of indirubins on Notch-1 signaling, a pathway participating in cell cycle progression, invasion, migration, and apoptosis. Deregulation of Notch is observed in many types of human cancers and tumorigenesis. 10 has been found to suppress Notch-1 signaling through downregulation of GSK-3 [98], while 5'-nitroindirubin-3'-oxime induces cell cycle arrest possibly through blockage of Notch-1 signaling [99].

Finally, a less studied but very promising field for the implication of indirubins in biological processes involves the regulation of STAT3 signaling. STAT3 is a family of different transcription factors playing an important role in tumor survival/proliferation and inflammatory responses [100]. In STAT3, JAKs phosphorylate STAT3 and activate signaling for the transcription of specific target genes. Except JAKs, many other PKs implicate the activation of STAT3, like members of the Src family, PKC, EGFR, etc. [101]. Indirubin and derivatives such as $\mathbf{I O}$ and $\mathbf{5 I O}$ have been found to block STAT3 signaling through the inhibition of implicated PKs [102-104]. Recently, it has been shown that STAT3 activation is highly dependent on GSK-3 $\beta$, as specific inhibitors of the latter block the STAT3 DNA binding ability [105].

\section{Structural diversity and selectivity}

Since the identification of indirubin as a protein kinase inhibitor, several analogues have been designed and synthesized targeting the kinome. After several years of research, the vast range of analogues existing allows for structure/activity relationships to be established. Halogenated indirubins share a special place among those analogues as they offer a versatile tool for the exploration of specific kinase inhibition [106], and also a matrix upon more selective and active analogues was later on developed ( $\bullet$ Fig. 3 ). By reviewing the literature existing so far on indirubins and kinase inhibition, the shifting from the mediocrely active and nonspecific indirubin to variably substituted indirubins with enhanced kinase inhibition involves the identification of natural 6BI as a GSK-3 $\beta$ specific inhibitor [39]. Earlier reports on synthetic 5-halogenated indirubins indicated an antitumor activity [107], although this was not correlated to kinase inhibition until indirubins were collectively acknowledged as kinase inhibitors [15].

During the last decade, lead indirubins have been established for the most important PK targets identified, namely 6BIO for GSK$3 \beta$ inhibition [38] and indirubin-5-sulfonate for CDK2 (E622) [65], focusing on two different axes targeting cell proliferation on the one hand and neurodegeneration on the other. It is also worth mentioning that although E622 is not halogenated, its design was based on 5-halogenated indirubins with antitumor properties, with the halogen being replaced by a group givingenhanced druggability to the scaffold. The latter is also the case with $3^{\prime}$ oxime analogues and 6BIO, which were developed in terms of rendering the indirubin scaffold more soluble.

- Fig. 3 provides a quick overview on the kinase inhibitory properties of simple substituted indirubins, which possess at least one halogen atom in their core. For indirubin itself, the nonspecificity especially among the examined CDKs is evident. Substitution on position 5 generally enhances the PK inhibition potency, although it eliminates selectivity. This is particularly true for 5iodo analogues, which exhibit nanomolar range activity both in CDKs and GSK-3 $\beta$. Recently, a series of new 5,5' bisubstituted analogues were developed showing great potency towards CDK2 [57].

As substitution is shifting towards position 6, greater selectivity towards GSK-3 $\beta$ is accomplished peaking for 5,6 bisubstituted analogues with the bromine atom on position 6 . The affinity of 6-bromo-substituted indirubins and 6BIO in particular, with GSK-3 $\beta$ in comparison with CDKs, was elucidated with the crystallographic studies of the complex 6BIO/GSK-3 $\beta$ [51], taking into account the previous $X$-ray structures of indirubin-5-sulfonate (E226) with CDK2 [15] and the complex CDK2/cyclin A [108] and indirubin-3'-oxime with CDK5/p25 [39]. Further crystallographic data [109] confirm the pharmacophore of the indirubin scaffold in most of the analogues due to the fact that PKs are to a large extent conserved.

The pharmacophore of the indirubin scaffold consists of the lactam amide nitrogen, lactam amide oxygen, and cyclic pyrole nitrogen ( Fig. 5B). In the case of E226 and CDK2 (both inactive and activated by cyclin $A$ ), the lactam and pyrrole nitrogen atoms act as hydrogen bond donors to the oxygen atoms of Glu81 and Leu83, respectively, while the amine group of Leu83 forms an additional bond with the scaffold's lactam oxygen. In the case of 10 and CDK5/p25, the corresponding amino acid residues are Glu81 and Cys83, while for $\mathbf{6 B I O}$ and GSK-3 $\beta$, they correspond to Asp133 and Val135. In all of the tested kinases, the indirubin scaffold is inserted into the ATP binding pocket located between the two lobes of the enzyme. For analogues methylated on the lactame nitrogen ( $N$-methylindirubins), PK inhibitory activity is lost, due to its incapability to act as a hydrogen bond donor, and therefore such analogues are used as negative controls for indirubin kinase inhibition ( $\odot$ Fig. 5B).

As proposed from crystallographic studies and molecular modeling studies, the selectivity of $6 \mathrm{BIO}$ to GSK-3 $\beta$ versus CDKs is related to minor differences in the binding pocket of the enzymes. GSK-3 $\beta$ with the relatively small Leu132 provides a more spacious environment for the bromine atom to be inserted in the back of the cavity, whereas in CDKs 1,2 , and 5, this area is restricted due to the bulkier Phe80 ( Fig. 5 A). By taking into account the topology of the binding pockets, the results of $\square$ Fig. 3 can be rationalized for all indirubin analogues discussed. The highly unspecific 5-halogenated indirubins are able to associate with all of the competitive kinases to some extent, as the 5-sub- 


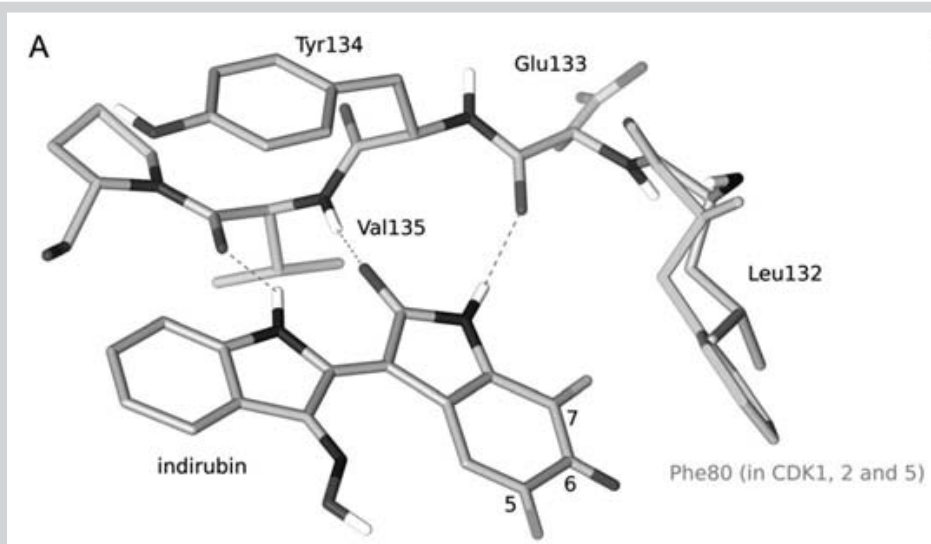

B

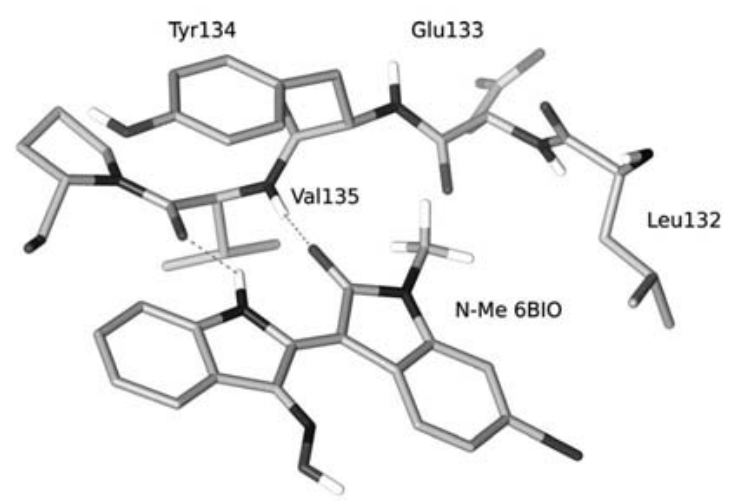

Fig.5 A Comparative representation of 5-, 6-, and 7-substituted indirubin analogues into the binding cavities of CDKs and GSK-3. B Steric hindrance in the binding cavity of GSK-3 for $\mathrm{N}$-methylated indirubin analogues, leading to non-inhibition. stituent is directed outside of the binding pocket. 2D and 3D QSAR studies on halogenated indirubins show that affinity with GSK-3 $\beta$ is enhanced with the substitution in positions $5 / 6$ with electron-withdrawing atoms such as halogens, while similar substitution on positions $4 / 7$ is not favorable [110]. As seen in 0 Fig. 3, 5- and 6-bromo or iodo, as well as 5,6-bisubstituted analogues possess the greatest activity towards GSK-3 $\beta$.

Astonishing is the case of 7-substituted analogues, which stand out among halogenated indirubins as cases of no significant PK inhibitory activity but with remarkable cytotoxicity. As seen in - Fig. 3, 7-halogenated indirubins inhibit Aurora kinase C [15] and FLT3, but this fact is unlikely to be connected to the necrotic cell death induced by 7BIO [71]. This is also supported by the low potential of 7-brominated analogues to insert into the binding pockets of the kinases as the substituent is directed in the less spacious interior of the cavity ( $\odot$ Fig. 5 A).

\section{Effect on stem cells and progenitors}

The establishment of $\mathbf{6 B I O}$ as a potent and selective GSK-3 inhibitor was followed by a very promising discovery concerning its effect on stem cells. $\mathbf{6 B I O}$ was found to maintain the undifferentiated phenotype of both human and mouse embryonic stem cells (HESCs and MESCs, respectively), sustaining their pluripotency possibly through Wnt activation [111], and also to decrease MESCs proliferation rates, not due to apoptosis but rather accumulation of the cells in the G1 phase [112]. Recently, it has been proposed that this delay of the cell cycle progression is due to the downregulation of cyclin D1 and the upregulation of $\mathrm{p} 57$ by $6 \mathrm{BIO}$ [113]. Results from different research groups, report that $6 \mathrm{BIO}$ appears to also stimulate the LIF (leukemia inducing factor) signal, which acts synergistically with Wnt activation in terms of maintaining the undifferentiated state of MESCs [114]. In the absence of LIF/Wnt signaling, it has been proposed that ESCs renewal could be a result of elevated myc levels and subsequent stem cell stability [115].

GSK-3 function is also a key factor in hematopoiesis and the expansion of hematopoietic stem cells into mature blood cells. 6BIO has been found to promote and inhibit the ex vivo expansion of umbillical cord blood hematopoietic stem cells (UCB HSCs) in low and high concentrations, respectively [116,117]. GSK-3 inhibition by $\mathbf{6 B I O}$ also causes a decrease in proliferation of adult olfactory epithelial human neural precursors accompanied by an increase of differentiation markers, thus suggesting the promotion of early neuronal differentiation [118].

Similarly, human mesenchymal stem cells (hMSCs) from bone marrow are regarded as putative osteoblast progenitors differentiating into osteoblasts in vitro. 6BIO induces the cell cycle inhibition of hMSCs while enhancing the early stage of osteogenesis, as mineralization is observed after treatment [119]. In particular with osteoblasts, the latter is supported by in vivo experiments on bone mass loss after extensive glucocorticoid treatment, during which treatment with $6 \mathrm{BIO}$ resulted in the attenuation of bone mineralization loss [120].

Despite the vague mechanism of action concerning stem cells and progenitors, $6 \mathrm{BIO}$ was found to inhibit the differentiation of $\mathrm{T}$ cells while arresting the development of CD8 + T cells into effector cells [121] and also inhibit the proliferation of HMADSCs (human adipose derived stem cells) and their adipogenic differentiation [122]. Furthermore, 6BIO significantly enhances the ability of ESCs to reprogram somatic cells after fusion thus allowing the dedifferentiation of the hybrids [123]. Finally, 6BIO prevents the process of epithelial to mesenchymal spontaneous transition (EMT) of HESCs when cultured also under feeder-free conditions, although it was not able to expand HESCs in a long-term culture system [124]. Paradoxically, 6BIO was found to be associated with reduced cell proliferation of human islet-derived precursor cells (HIPCs), which are characterized as mesenchymal stem cells, able to differentiate into islet-like structures [125].

Another interesting application of $\mathbf{6 B I O}$ discovered recently is the ability to facilitate the derivation of ESCs from blastocysts when used alone or in combination with LIF $[126,127]$. When an inner cell mass of blastocysts (ICM) able to provide ESCs is incubated with $2 \mu \mathrm{M}$ 6BIO, all of the formed colonies provide ESCs giving a 4-fold increase in the efficiency of the derivation. Recent studies report a fivefold increase of ESCs derivation when multiple factors are utilized along with 6BIO [128]. In addition, 6BIO in combination with fibroblast growth factor (FGF) can contribute in the formation of porcine embryonic germ cells (EGCs) colonies, increasing the mitosis index and maintaining the undifferentiated state [129]. Finally, 6BIO was found to increase the expression of genes and pluripotency markers in ESCs suggesting that upregulation of stemness genes keeps the cells in a self-renewing pluripotent state [130]. 


\section{Effect on leukemia and solid tumors}

Anticancer properties of halogenated indirubins and related analogues seem to focus on three basic concepts: inhibition of CDKs and cell cycle arrest, restrictions on signaling pathways and especially STAT3, and the induction of non-apoptotic cell death by 7BIO and certain 7-halogenated analogues [60,131].

Potential kinase inhibition, although it is not yet established, probably lies behind the antitumor properties of 5-carboxamide analogues (45-55) against LXFL529L lung cancer cells, with $\mathrm{IC}_{50}$ in the low $\mu \mathrm{M}$ range [66]. In addition, bromo- and methoxy-indirubin analogues have been examined for their capability of inducing apoptosis in neuroblastoma cells, although the mechanism of apoptosis is not yet clarified [52].

Furthermore, 5-substituted indirubin derivatives (E622, 40-44), besides the potent inhibition of CDKs, have been shown to block STAT3 signaling, inhibit Src, and finally induce apoptosis in human breast cancer cells [132]. Most importantly, 6BIO induces apoptosis in human melanoma cells accompanied with inhibition of STAT3 signaling while suppressing in vivo tumor growth in xenograph human melanoma models [133]. In addition, the synergy between all these factors is possibly the cause of the inhibition of proliferation observed under treatment with $\mathbf{6 B I O}$ of malignant lymphoid cells [134].

GSK-3 inhibitors are still under investigation as antileukemic factors [116] since limited literature has been published on this topic. 6BIO exerts an in vivo curative effect against leukemia animal models as well as specific cytotoxicity in vitro against rapidly dividing leukemia blasts [135]. In addition, GSK-3 $\beta$ inhibition by 6BIO was found to inhibit MLL leukemia cell proliferation and transformation [136]. An assumption of GSK-3 $\beta$ inhibition leading to apoptosis is made, although indirubins are also potential inhibitors of FLT3, which is often mutated in patients with acute myeloid leukemia (AML) $[58,88]$. Finally, indirubin type inhibitors of GSK-3 have been found to improve survival in gliomabearing mice [137] while $6 \mathrm{BIO}$ is suppressing telomerase activity probably via GSK-3 $\beta$ inhibition, without showing an overt toxicity [138].

\section{Effect on cardiac cells}

Results by several studies reveal that 6BIO also affects cardiac cells, both differentiated and undifferentiated, as a potent GSK$3 \beta$ inhibitor [139]. Specifically, 6BIO enhances the survival of human cardiac stem cells (HCSCs) while stimulating their growth kinetics [140], in addition to the fact that 6BIO treatment of postmitotic highly differentiated cardiac cells promoted their proliferation $[141,142]$. 6BIO via inhibition of GSK-3 $\beta$ is found to expand the pivotal role of Isl1+ cardiovascular progenitors to cardiogenesis in a dose-dependent manner without significant suppression of apoptosis [143]. All those findings are of great importance concerning the repair and diversification of the heart [144]. Another aspect of the effect of halogenated indirubins on cardiac cells is portrayed in studies concerning the neuronal or myocardial damage induced by ischemia/hypoxia. 6BIO was found to prevent ischemic neuronal death in oxygen/glucose deprivation conditions [145], while in a similar in vitro model of neural progenitors it was found to rescue neurons either as a preconditioning technique or as a post-injury system [146]. Moreover, treatment of hypertrophied rabbit hearts with $\mathbf{5 1 0}$ was found to increase tolerance to ischemia through GSK-3 $\beta$ inhibition, suggesting a practical treatment in the protection of hypertrophied hearts during open heart surgeries [147].
Furthermore, under the scope of investigating how histone deacetylase-2 (Hdac2) deficiency attenuates cardiac hypertrophy in mice, it was found that intraperitoneal admission of $\mathbf{6 B I O}$ in mice is capable of inhibiting in vivo GSK-3 $\beta$, leading to increased heart-body weight ratios [148].

\section{Effect on renal and pancreatic cells}

6BIO through mediation in the Wnt and Akt signaling has a significant effect on kidney and pancreatic tissues. When diabetic Wistar rats were administered $\mathbf{6 B I O}$ subcutaneously, it was found that GSK-3 signaling was modulated and apoptosis of the cells adjacent to globeruli was reduced in the diabetic kidney followed by reduced urinary protein secretion [149]. In addition, exposing mouse kidney mesenchymes in $\mathbf{6 B I O}$ triggers nephron segregation and epithelial differentiation [150]. Finally, inhibition of GSK-3 $\beta$ by 6 BIO after the treatment of mice with endotaxemic renal failure resulted in the reduction of nephrotoxicity and mortality by sepsis [151].

6BIO also is found to promote the replication and survival of pancreatic beta cells [152] and the proliferation of facultative hepatic stem/progenitor cells [153], proposing that inhibition of GSK-3 and small molecule inhibitors could have applications in regenerative therapies.

\section{Effect on neurodegeneration}

6BIO's ability to affect CNS cells derives from its most important property of being a selective and potent GSK-3 $\beta$ inhibitor. Abnormal phosphorylation events related to GSK-3 $\beta$ activity have been established in neurodegenerative states, and those findings lead to the further investigation of GSK-3 $\beta$ inhibitors as neuroprotective agents [154]. 6BIO was found to reverse okadaic acid-induced multi-substrate phosphorylation [155], tau phosphorylation, and apoptosis in cultured cortical neurons, with very limited toxicity $[156,157]$. Most importantly, this pattern of neuroprotection was repeated with the use of three more 6BIO 3'-substituted derivatives, even though they are not as potent GSK-3 $\beta$ inhibitors as 6 BIO $[59,158]$. GSK-3 $\beta$ inhibition with 5 IIO has shown a neuroprotective effect and a stress response reduction in human neurons [159]. A similar effect is also observed with HIV-induced neurotoxicity to human neurons where $6 \mathrm{BIO}$ was found to significantly reduce the activity of proapoptotic caspases 3,7 [160], and with cortical neuron cells suffering endoplasmic reticulum stress where $\mathbf{6 B I O}$ treatment resulted in attenuation of $\mathrm{CHOP}$ expression, suggesting a role of this factor in neuronal cell death [161]. In vivo experiments in mice suffering from kainate acid-induced neurotoxicity have shown that brominated indirubin analogues $(6 \mathrm{BIO}, 5 \mathrm{BIO}$, and 5A6BI) reduce mortality and striatal astrogliosis [162].

Although GSK-3 $\beta$ inhibition is considered a putative target for neurogeneration, results from different research groups suggest that strong GSK-3 $\beta$ inhibition from the acetoxime analogue of 6BIO, which is even more potent against GSK-3 $\beta$, leads to inhibition of hippocampal axon growth [163] and neurite axon growth [164]. This effect is observed in a dose-dependent manner, thus leaving open the possibility of a therapeutic effect of inhibitors in low doses.

\section{Effect on protozoans and other parasites}

The antiprotozoan properties of halogenated indirubins are to a large extent associated with the potential of inhibiting kinases, like the leishmanian homologues of CDK1 (CRK3), GSK-3 (LdGSK-3), and MAPKs, whose functional role in the life cycle of 
the parasite can be even more important than in mammalian cells.

After screening of a panel of indirubins, the 6-brominated analogues proved to be the most effective against the growth of amastigotes and promastigotes of Leishmania donovani, a fact attributed to kinase inhibition. Interestingly, $\mathbf{6 B I O}$ was found to possess greater affinity with CRK3 (leishmanian homologue of CDK-1) than LdGSK-3 (homologue of GSK-3), while the bisubstituted 5Me6BIO (78) associated greatly with the latter [165]. On the other hand, 5 IIO was found to inhibit the growth of promastigotes and amastigotes of $L$. mexicana though without any significant potency against CRK3 [166] while docking studies indicated potential of leishmanian MAPK inhibition by 5-iodo substituted indirubins, placing them as candidates for antileishmanian treatment [167]. Indirubin analogues also have shown modest in vitro activity against Toxoplasma gondii tachyzoites in the micromolar range [168].

The activity of $6 \mathrm{BIO}$ expands also to arachnoids of Rhipicephalus microplus, in which the homologue of GSK-3 has been elucidated and found to play an important role in embryonic processes. 6BIO was found to cause a reduction in larvae hatching and oviposition of females [169].

\section{Interaction of indirubins with the aryl hydrocarbon receptor}

Aryl hydrocarbon receptor (AhR), also known as dioxin receptor, is a cotranscription factor mediating the toxicological and biological properties of TCDD (2,3,7,8-tetrachlorodibenzo-p-dioxin), PAHs, and HAHs (polyciclic and halogenated aromatic hydrocarbons) [170]. Binding of the ligand to the receptor is essential for the manifestation of toxicological response including hepatotoxicity, immunotoxicity, and tumor promotion [171]. It remained an orphan receptor without an endogenous ligand being identified, up to 2001, when indirubin identified in human urine was found to contribute to the activity of the AhR $[16,172,173]$. Paradoxically, while long-term exposure to xenobiotics leads to an increased risk of malignancies [174], acute TCDD toxicity has been found to inhibit solid tumor proliferation through upregulation of endogenous CDK inhibitors [175]. The role of AhR in tumorigenesis is still to a large extent unidentified and under considerable investigation [176].

\section{Conclusion}

$\nabla$

Indirubins represent a very robust scaffold among naturally derived compounds and exhibit an outstanding versatility both as biological tools and bioactive factors. Small variations on the basic skeleton, as in the case of halogenated indirubins, have been proven to modulate significantly biological activity, leading to more active and selective PK inhibitors with fascinating applications as in the field of stem cells. All of the above, along with their charming history through the ages of natural product research and development, places them in the front line of nature-inspired drug discovery.

\section{Conflict of Interest}

$\nabla$

There are no conflicts of interest among the authors of this manuscript.

\section{References}

1 Clark RJH, Cooksey CJ, Daniels MAM, Withnall R. Indigo, woad, and Tyrian Purple: important vat dyes from antiquity to the present. Endeavour 1993; 17: 191-199

2 Weston $\mathrm{CH}$. Observations on the manner of manufacturing indigo in the Southern Provinces of India; with some remarks on its chemical changes and combinations. J Franklin I 1829; 8: 233-240

3 Doménech A, Doménech-Carbó MT, del Rio MS, Goberna S, Lima E. Evidence of topological indigo/dehydroindigo isomers in maya blue-like complexes prepared from palygorskite and sepiolite. J Phys Chem C 2009; 113: 12118-12131

4 Ricketts R. Polygonum tinctorium: contemporary indigo farming and processing in Japan. In: Meijer L, Guyard N, Skaltsounis AL, Eisenbrand $\mathrm{G}$, editors. Indirubin, the red shade of indigo. Roscoff, France: Life in Progress Editions; 2006: 147-156

5 McGovern PE, Michel RH. Royal purple dye: tracing the chemical origins of the industry. Anal Chem 1985; 57: 1514-1522

6 Hoffman RC, Zilber RC, Hoffman RE. NMR spectroscopic study of the Murex trunculus dyeing process. Magn Reson Chem 2010; 48: 892-895

7 Van Elslande E, Lecomte S, Le Ho AS. Micro-Raman spectroscopy (MRS) and surface-enhanced Raman scattering (SERS) on organic colourants in archaeological pigment. J Raman Spectrosc 2008; 39: 1001-1006

8 March RE, Papanastasiou M, McMahon AW, Allen NS. An investigation of paint from a mural in the church of Sainte Madeleine, Manas, France. J Mass Spectrom 2011; 46: 816-820

9 Dupont C. The dog whelk Nucella lapillus and dye extraction activities from the iron age to the middle ages along the Atlantic coast of France. J Island Coastal Archeol 2011; 6: 3-23

10 Withnall R, Patel D, Cooksey C, Naegel L. Chemical studies of the purple dye of Purpura pansa. Dyes Hist Archaeol 2003; 19: 109-117

11 Wu LM, Yang YP, Zhu ZH Studies on the active principles of Indigofera tinctoria in the treatment of CML. Comm Chin Herb Med 1979; 9: 6-8

12 Sato N, Meijer L, Skaltsounis L, Greengard P, Brivanlou AH. Maintenance of pluripotency in human and mouse embryonic stem cells through activation of Wnt signaling by a pharmacological GSK-3 specific inhibitor. Nat Med 2004; 10: 55-63

13 Leclerc S, Garnier M, Hoessel R, Marko D, Bibb JA, Snyder GL, Greengard P, Biernat J, Wu YZ, Mandelkow EM, Eisenbrand G, Meijer L. Indirubin inhibits glycogen synthase kinase-3 beta and CDK5/p 25, two protein kinases involved in abnormal tau phosphorylation in Alzheimer's disease. A property common to most cyclin-dependent kinase inhibitors? J Biol Chem 2001; 276: 251-260

14 Hoessel R, Leclerc S, Endicott JA, Nobel ME, Lawrie A, Tunnah P, Leost M, Damiens E, Marie D, Marko D, Niederberger E, Tang W, Eisenbrand G, Meijer $L$. Indirubin, the active constituent of a Chinese antileukaemia medicine, inhibits cyclin dependent kinases. Nat Cell Biol 1999; 1: 60-67

15 Myrianthopoulos V, Magiatis P, Ferandin Y, Skaltsounis AL, Meijer L, Mikros $E$. An integrated computational approach to the phenomenon of potent and selective inhibition of aurora kinases $B$ and $C$ by a series of 7-substituted indirubins. J Med Chem 2007; 50: 4027-4037

16 Adachi J, Mori Y, Matsui S, Takigami H, Fujino J, Kitagawa H, Miller 3rd CA, Kato T, Saeki K, Matsuda T. Indirubin and indigo are potent aryl hydrocarbon receptor ligands present in human urine. J Biol Chem 2001; 276: 31475-31478

17 Knockaert M, Blondell M, Bach S, Leost M, Elbi C, Hager GL, Nagy SR, Han $D$, Denison M, Ffrench M, Ryan XP, Magiatis P, Polychronopoulos P, Greengard P, Skaltsounis L, Meijer L. Independent actions on cyclin-dependent kinases and aryl hydrocarbon receptor mediate the antiproliferative effects of indirubins. Oncogene 2004; 23: 4400-4412

18 Grothaus PG, Cragg GM, Newman DJ. Plant natural products in anticancer drug discovery. Curr Org Chem 2010; 14: 1781-1791

19 Schunck E. On the formation of indigo-blue. Part I. Mem Manchester Lit Phil Soc Ser 2 1855; 2: 177-208

20 Maugard T, Enaud E, Choisy P, Legoy MD. Identification of an indigo precursor from leaves of Isatis tinctoria (Woad). Phytochemistry 2001; 58 : 897-904

21 Guengerich PF, Martin MV, McCormick WA, Nguyen LP, Glover E, Bradfield CA. Aryl hydrocarbon receptor response to indigoids in vitro and in vivo. Arch Biochem Biophys 2004; 423: 309-316

22 Shiao CC, Weng CY, Chuang JC, Huang MS, Chen ZY. Purple urine bag syndrome: a community-based study and literature review. Nephrology (Carlton) 2008; 13: 554-559

23 Cooksey CJ. Tyrian purple: 6,6'-dibromoindigo and related compounds. Molecules 2001; 6: 736-769 
24 Oberthür C, Graf H, Hamburger M. The content of indigo precursors in Isatis tinctoria leaves-a comparative study of selected accessions and post-harvest treatments. Phytochemistry 2004; 65: 3261-3268

25 Oberthür C, Schneider B, Graf H, Hamburger M. The elusive indigo precursors in woad (Isatis tinctoria L.)-identification of the major indigo precursor, isatan $\mathrm{A}$, and a structure revision of isatan $\mathrm{B}$. Chem Biodivers 2004; 1 : 174-182

26 Chen H-J, Tsao H-H, Lo JG, Chiu K-H, Jen J-F. Supercritical fluid extraction coupled with solvent-less spray collection mode for rapid separation of indirubin and tryptanthrin from Folium Isatidis. Sep Sci Technol 2011; 46: 972-997

27 Friedländer P. Über den Farbstoff des antiken Purpurs aus Murex brandaris. Chem Ber 1909; 42: 765-770

28 Karapanagiotis I, de Villemereuil V, Magiatis P, Polychronopoulos P, Vougogiannopoulou K, Skaltsounis AL. Identification of the coloring constituents of four natural indigoid dyes. J Liq Chromatogr R T 2006; 29: 1491-1502

29 Baker JT, Sutherland MD. Pigments of marine animals. VIII. Precursors of 6,6'-dibromoindigotin (Tyrian Purple) from the mollusc Dicathais orbita gmelin. Tetrahedron Lett 1968; 1: 43-46

30 Baker JT, Duke CC. Isolation of choline and choline ester salts of tyrindoxyl sulphate from the marine molluscs Dicathais orbita and Mancinella keineri. Tetrahedron Lett 1976; 15: 1233-1234

31 Baker JT. Tyrian Purple: an ancient dye, a modern problem. Endeavour 1976; 33: 11-17

32 Fujise Y, Miwa K, Ito S. Structure of tyriverdin, the intermediate precursor of Tyrian purple. Chem Lett 1980; 6: 631-632

33 López Chávez FJ, Ríos Chávez P, Oyama K. Brominated precursors of Tyrian purple (C.I. Natural Violet 1) from Plicopurpura pansa, Plicopurpura columellaris, and Plicopurpura patula. Dyes Pigments 2009; 83: 7-13

34 Fouquet $\mathrm{H}$, Bielig $\mathrm{H}-\mathrm{J}$. Biological precursors and genesis of tyrian-purple. Angew Chem Int Ed 1971; 10: 816-817

35 Westley C, Benkendorff K. Sex-specific Tyrian purple genesis: precursor and pigment distribution in the reproductive system of the marine mollusc, Dicathais orbita. J Chem Ecol 2008; 34: 44-56

36 Benkendorff $K$, Bremner JB, Davies AR. Tyrian Purple precursors in the egg masses of the australian muricid Dicathais orbita: a possible defensive role. J Chem Ecol 2000; 26: 1037-1050

37 Benkendorff $K$, Bremner JB, Davies AR. Indole derivatives from the egg masses of Muricid molluscs. Molecules 2001; 6: 70-78

38 Magiatis P, Skaltsounis AL. From Hexaplex trunculus to new kinase inhibitory indirubins. In: Meijer L, Guyard N, Skaltsounis AL, Eisenbrand $\mathrm{G}$, editors. Indirubin, the red shade of indigo. Roscoff, France: Life in Progress Editions; 2006: 147-156

39 Meijer L, Skaltsounis AL, Magiatis P, Polychronopoulos P, Knockaert M, Leost M, Ryan XP, Vonica CA, Brivanlou A, Dajani R, Crovace C, Tarricone C, Musacchio A, Roe SM, Pearl L, Greengard P. GSK-3-selective inhibitors derived from Tyrian purple indirubins. Chem Biol 2003; 10: 12551266

40 Puchalska M, Połeć-Pawlak K, Zadrozna I, Hryszko H, Jarosz M. Identification of indigoid dyes in natural organic pigments used in historical art objects by high-performance liquid chromatography coupled to electrospray ionization mass spectrometry. J Mass Spectrom 2004 39: $1441-1449$

41 Nowik W, Marcinowska R, Kusyk K, Cardon D, Trojanowicz M. High performance liquid chromatography of slightly soluble brominated indigoids from Tyrian purple. J Chromatogr A 2011; 1218: 1244-1252

42 Benkendorff $K$, Westley CB, Gallardo CS. Observations on the production of purple pigments in the egg capsules, hypobranchial and reproductive glands from seven species of Muricidae (Gastropoda: Mollusca). Invertebr Reprod Dev 2004; 46: 93-102

43 Edwards $V$, Benkendorff $K$, Young $F$. Marine compounds selectively induce apoptosis in female reproductive cancer cells but not in primary-derived human reproductive granulosa cells. Mar Drugs 2012; 10: $64-83$

44 Westley CB, Mclver CM, Abbott CA, Le Leu RK, Benkendorff K. Enhanced acute apoptotic response to azoxymethane-induced DNA damage in the rodent colonic epithelium by Tyrian purple precursors: a potential colorectal cancer chemopreventative. Cancer Biol Ther 2010; 9: 371379

45 Bayer A. Ueber die Verbindungen der Indigogruppe. Chem Ber 1883; 16: 2188-2204

46 Russel GA, Kaupp G. Oxidation of carbanions. IV. Oxidation of indoxyl to indigo in basic solution. J Am Chem Soc 1969; 91: 3851-3859
47 Clarck RJH, Cooksey CJ. Bromoindirubins: the synthesis and properties of minor components of Tyrian purple and the composition of the colorant from Nucella lapillus. J Soc Dyers Colour 1997; 113: 316-321

48 Sandmeyer $T$. Ueber Isonitrosoacetanilide und deren Kondensation zu Isatinen. Helv Chim Acta 1919; 2: 234-242

49 Zhang A, Yu M, Lan T, Liu Z, Mao Z. Novel synthesis of 4- or 6-substituted indirubin derivatives. Synth Commun 2010; 40: 3125-3134

50 Tanoue Y, Ikoma Y, Kai N, Nagai T. Synthesis of halogenoindirubins. J Heterocyclic Chem 2009; 46: 1016-1018

51 Polychronopoulos P, Magiatis P, Skaltsounis AL, Myrianthopoulos V, Mikros E, Tarricone A, Musacchio A, Roe SM, Pearl L, Leost M, Greengard P, Meijer $L$. Structural basis for the synthesis of indirubins as potent and selective inhibitors of glycogen synthase kinase-3 and cyclin-dependent kinases. J Med Chem 2004; 47: 935-946

52 Saito H, Tabata K, Hanada S, Kanda Y, Suzuki T, Miyairi S. Synthesis of methoxy- and bromo-substituted indirubins and their activities on apoptosis induction in human neuroblastoma cells. Bioorg Med Chem Lett 2011; 21: 5370-5373

53 Beauchard A, Laborie H, Rouillard H, Lozach O, Ferandin Y, Le Guével R, Guguen-Guillouzo C, Meijer L, Besson T, Thiéry V. Synthesis and kinase inhibitory activity of novel substituted indigoids. Bioorg Med Chem 2009; 17: 6257-6263

54 Beauchard A, Ferandin Y, Frère S, Lozach O, Blairvacq M, Meijer L, Thiéry $V$, Besson T. Synthesis of novel 5-substituted indirubins as protein kinases inhibitors. Bioorg Med Chem 2006; 14: 6434-6443

55 Park EJ, Choi SJ, Kim YC, Lee SH, Park SW, Lee SK. Novel small molecule activators of beta-catenin-mediated signaling pathway: structure-activity relationships of indirubins. Bioorg Med Chem Lett 2009; 19: 2282-2284

56 Moon MJ, Lee SK, Lee JW, Song WK, Kim SW, Kim JI, Cho C, Choi SJ, Kim YC. Synthesis and structure-activity relationships of novel indirubin derivatives as potent anti-proliferative agents with CDK2 inhibitory activities. Bioorg Med Chem 2006; 14: 237-246

57 Choi SJ, Lee JE, Jeong SY, Im I, Lee SD, Lee EJ, Lee SK, Kwon SM, Ahn SG Yoon JH, Han SY, Kim JI, Kim YC. 5-5'-substituted indirubin-3'-oxime derivatives as potent cyclin-dependent kinase inhibitors with anticancer activity. J Med Chem 2010; 54: 3696-3706

58 Choi SJ, Moon MJ, Lee SD, Choi SU, Han SY, Kim YC. Indirubin derivatives as potent FLT3 inhibitors with anti-proliferative activity of acute myeloid leukemic cells. Bioorg Med Chem Lett 2010; 20: 2033-2037

59 Vougogiannopoulou K, Ferandin Y, Bettayeb K, Myrianthopoulos V, Lozach O, Fan Y, Johnson CH, Magiatis P, Skaltsounis AL, Mikros E, Meijer L. Soluble 3',6-substituted indirubins with enhanced selectivity toward glycogen synthase kinase -3 alter circadian period. J Med Chem 2008; 51: 6421-6431

60 Jautelat R, Brumby T, Schäfer M, Briem H, Eisenbrand G, Schwahn S, Krüger M, Lücking U, Prien O, Siemeister G. From the insoluble dye indirubin towards highly active, soluble CDK2-inhibitors. Chembiochem 2005; 6: 531-540

61 Ferandin $Y$, Bettayeb $K$, Kritsanida $M$, Lozach $O$, Polychronopoulos $P$, Magiatis P, Skaltsounis AL, Meijer L. 3'-Substituted 7-halogenoindirubins, a new class of cell death inducing agents. J Med Chem 2006; 49: 4638-4649

62 Libnow S, Methling K, Hein M, Michalik D, Harms M, Wende K, Flemming A, Köckerling M, Reinke H, Bednarski PJ, Lalk M, Langer P. Synthesis of indirubin- $\mathrm{N}^{\prime}$-glycosides and their anti-proliferative activity against human cancer cell lines. Bioorg Med Chem 2008; 16: 5570-5583

63 Libnow S, Hein $M$, Langer $P$. The first $N$-glycosylated indoxyls and their application to the synthesis of indirubin- $\mathrm{N}$-glycosides (purple sugars). Synlett 2009; 2009: 221-224

64 Kritsanida M, Magiatis P, Skaltsounis AL, Peng Y, Li P, Wennogle LP. Synthesis and antiproliferative activity of 7-azaindirubin-3'-oxime, a 7-aza isostere of the natural indirubin pharmacophore. J Nat Prod 2009; 72: 2199-2202

65 Wang ZH, Li WY, Li FL, Zhang L, Hua WY, ChengJC, Yao QZ. Synthesis and antitumor activity of 7-azaindirubin. Chin Chem Lett 2009; 20: 542544

66 Cheng X, Rasqué P, Vatter S, Merz KH, Eisenbrand G. Synthesis and cytotoxicity of novel indirubin-5-carboxamides. Bioorg Med Chem 2010; 18: 4509-4515

67 Schwartz PA, Murray BW. Protein kinase biochemistry and drug discovery. Bioorg Chem 2011; 39: 192-210

68 Cohen P. Protein kinases-the major drug targets of the twenty-first century? Nat Rev Drug Discov 2002; 1: 309-315 
69 Hunter T, Cooper JA. Protein-tyrosine kinases. Annu Rev Biochem 1985; 54: 897-930

70 Xingi E, Smirlis D, Myrianthopoulos V, Magiatis P, Grant KM, Meijer L, Mikros E, Skaltsounis AL, Soteriadou K. 6-Br-5-methylindirubin-3'-oXime (5-Me-6-BIO) targeting the leishmanial glycogen synthase kinase-3 (GSK-3) short form affects cell-cycle progression and induces apoptosis-like death: exploitation of GSK-3 for treating leishmaniasis. Int J Parasitol 2009; 39: 1289-1303

71 Ribas J, Bettayeb K, Ferandin Y, Knockaert M, Garrofé-Ochoa X, Totzke F, Schächtele C, Mester J, Polychronopoulos P, Magiatis P, Skaltsounis AL, Boix J, Meijer L. 7-Bromoindirubin-3'-oxime induces caspase-independent cell death. Oncogene 2006; 25: 6304-6318

72 Manning G, Whyte DB, Martinez R, Hunter T, Sudarsanam S. The protein kinase complement of the human genome. Science 2002; 298: 1912 1934

73 Norbury C, Nurse P. Animal cell cycles and their control. Annu Rev Biochem 1992; 61: 441-470

74 Cicenas J, Valius $M$. The CDK inhibitors in cancer research and therapy. J Cancer Res Clin Oncol 2011; 137: 1409-1418

75 Galons H, Oumata N, Meijer L. Cyclin-dependent kinase inhibitors: a survey of recent patent literature. Expert Opin Ther Pat 2010; 20: 377-404

76 Rizzolio F, Tuccinardi T, Caligiuri I, Lucchetti C, Giordano A. CDK inhibitors: from the bench to clinical trials. Curr Drug Targets 2010; 11: 279-290

77 Knockaert M, Greengard P, Meijer L. Pharmacological inhibitors of cyclin-dependent kinases. Trends Pharmacol Sci 2002; 23: 417-425

78 Lim AC, Qi RZ. Cyclin-dependent kinases in neural development and degeneration. J Alzheimers Dis 2003; 5: 329-335

79 Martinez A, Castro A, Dorronsoro I, Alonso M. Glycogen synthase kinase 3 (GSK-3) inhibitors as new promising drugs for diabetes, neurodegeneration, cancer, and inflammation. Med Res Rev 2002; 22: 373-384

80 Boutajangout A, Sigurdsson EM, Krishnamurthy PK. Tau as a therapeutic target for Alzheimer's disease. Curr Alzheimer Res 2011; 8: 666-677

81 Huang $\mathrm{H}-\mathrm{C}$, O'Brien WT, Klein PS. Targeting glycogen synthase kinase-3 in Alzheimer's disease. Drug Discov Today Ther Strateg 2006; 3: 613619

82 Koistinaho J, Malm T, Goldsteins G. Glycogen synthase kinase-3ß: a mediator of inflammation in Alzheimer's disease? Int J Alzheimers Dis 2011; 2011: 129753

83 Picchini AM, Manji HK, Gould TD. GSK-3 and neurotrophic signaling: Novel targets underlying the pathophysiology and treatment of mood disorders? Drug Discov Today Dis Mech 2004; 1: 419-428

84 Freyberg Z, Ferrando SJ, Javitch JA. Roles of the Akt/GSK-3 and Wnt signaling pathways in schizophrenia and antipsychotic drug action. Am J Psychiatry 2010; 167: 388-396

85 Hoeppner LH, Secreto FJ, Westendorf JJ. Wnt signaling as a therapeutic target for bone diseases. Expert Opin Ther Targets 2009; 13: 485-496

86 Ougolkov AV, Billadeau DD. Targeting GSK-3: a promising approach for cancer therapy? Future Oncol 2006; 2: 91-100

87 Hardt SE, Sadoshima J. Glycogen synthase kinase-3beta: a novel regulator of cardiac hypertrophy and development. Circ Res 2002; 90: 10551063

88 Phukan S, Babu VS, Kannoji A, Hariharan R, Balaji VN. GSK3beta: role in therapeutic landscape and development of modulators. Br J Pharmacol 2010; 160: 1-19

89 GSK-3 inhibitor IX (361550) product details, specifications and data sheets; Available at http://www.merckmillipore.com/greece/ life-science-research/gsk-3-inhibitor-ix/EMD_BIO-361550/p_R66b. s1LTrMAAAEWx2EfVhTm

90 Han S-Y, Ahn JH, Shin CY, Choi SU. Effects of indirubin derivatives on the FLT3 activity and growth of acute myeloid leukemia cell lines. Drug Develop Res 2010; 71: 221-227

91 Luo C, Laaja P. Inhibitors of JAKs/STATs and the kinases: a possible new cluster of drugs. Drug Discov Today 2004; 9: 268-275

92 Zahler S, Tietze S, Totzke F, Kubbutat M, Meijer L, Vollmar AM, Apostolakis $J$. Inverse in silico screening for identification of kinase inhibitor targets. Chem Biol 2007; 14: 1207-1214

93 Forde JE, Dale TC. Glycogen synthase kinase 3: a key regulator of cellular fate. Cell Mol Life Sci 2007; 64: 1930-1944

94 Toledo EM, Colombres M, Inestrosa NC. Wnt signaling in neuroprotection and stem cell differentiation. Prog Neurobiol 2008; 86: 281-296

95 Yao H, Ashihara E, Maekawa T. Targeting the Wnt/ $\beta$-catenin signaling pathway in human cancers. Expert Opin Ther Targets 2011; 15: 873887
96 Schnitzer SE, Schmid T, Zhou J, Eisenbrand G, Brüne B. Inhibition of GSK3beta by indirubins restores HIF-1alpha accumulation under prolonged periods of hypoxia/anoxia. FEBS Lett 2005; 579: 529-533

97 Sinha D, Wang Z, Ruchalski KL, Levine JS, Krishnan S, Lieberthal W, Schwartz JH, Borkan SC. Lithium activates the Wnt and phosphatidylinositol 3-kinase Akt signaling pathways to promote cell survival in the absence of soluble survival factors. Am J Physiol Renal Physiol 2005; 288: F703-F713

98 Lee MJ, Kim MY, Mo JS, Ann EJ, Seo MS, Hong JA, Kim YC, Park HS. Indirubin-3'-monoxime, a derivative of a Chinese anti-leukemia medicine, inhibits Notch1 signaling. Cancer Lett 2008; 265: 215-225

99 Yoon JH, Kim SA, Kwon SM, Park JH, Park HS, Kim YC, Yoon JH, Ahn SG. 5'-Nitro-indirubinoxime induces G1 cell cycle arrest and apoptosis in salivary gland adenocarcinoma cells through the inhibition of Notch1 signaling. Biochim Biophys Acta 2010; 1800: 352-358

100 Aggarwal BB, Sethi G, Ahn KS, Sandur SK, Pandey MK, Kunnumakkara $A B$, Sung $B$, Ichikawa $H$. Targeting signal-transducer-and-activatorof-transcription-3 for prevention and therapy of cancer: modern target but ancient solution. Ann NY Acad Sci 2006; 1091: 151-169

101 Song L, Turkson J, Karras JG, Jove R, Haura EB. Activation of Stat3 by receptor tyrosine kinases and cytokines regulates survival in human non-small cell carcinoma cells. Oncogene 2003; 22: 4150-4165

102 Zhang X, Song Y, Wu Y, Dong Y, Lai L, Zhang J, Lu B, Dai F, He L, Liu M, Yi $Z$. Indirubin inhibits tumor growth by antitumor angiogenesis via blocking VEGFR2-mediated JAK/STAT3 signaling in endothelial cell. Int J Cancer 2011; 129: 2502-2511

103 Schwaiberger AV, Heiss EH, Cabaravdic M, Oberan T, Zaujec J, Schachner D, Uhrin P, Atanasov AG, Breuss JM, Binder BR, Dirsch VM. Indirubin-3'monoxime blocks vascular smooth muscle cell proliferation by inhibition of signal transducer and activator of transcription 3 signaling and reduces neointima formation in vivo. Arterioscler Thromb Vasc Biol 2010; 30: 2475-2481

104 Menschikowski M, Hagelgans A, Hempel U, Siegert G. Glycogen synthase kinase-3beta negatively regulates group IIA phospholipase A2 expression in human aortic smooth muscle and HepG2 hepatoma cells. FEBS Lett 2004; 577: 81-86

105 Beurel E, Jope RS. Differential regulation of STAT family members by glycogen synthase kinase-3. J Biol Chem 2008; 283: 21 934-21 944

106 Kawakami F, Yamaguchi A, Suzuki K, Yamamoto T, Ohtsuki K. Biochemical characterization of phospholipids, sulfatide and heparin as potent stimulators for autophosphorylation of GSK-3beta and the GSK-3beta-mediated phosphorylation of myelin basic protein in vitro. J Biochem 2008; 143: 359-367

107 Gu YC, Li GL, Yang YP, Fu JP, Li CZ. Synthesis of some halogenated indirubin derivatives. Acta Pharmaceutica Sinica 1989; 24: 629-632

108 Davies TG, Tunnah P, Meijer L, Marko D, Eisenbrand G, Endicott JA, Noble $M E M$. Inhibitor binding to active and inactive CDK2: the crystal structure of CDK2-cyclin A/indirubin-5-sulfonate. Structure 2001; 9: 389397

109 Bertrand JA, Thieffine S, Vulpetti A, Cristiani C, Valsasina B, Knapp S, Kalisz HM, Flocco M. Structural characterization of the GSK-3beta active site using selective and non-selective ATP-mimetic inhibitors. J Mol Biol 2003; 333: 393-407

110 Lather V, Kristam R, Saini JS, Kristam R, Karthikeyan NA, Balaji VN. QSAR models for prediction of glycogen synthase kinase-3 $\beta$ inhibitory activity derivatives. QSAR Comb Sci 2008; 27: 718-728

111 Toledo EM, Colombres M, Inestrosa NC. Wnt signaling in neuroprotection and stem cell differentiation. Prog Neurobiol 2008; 86: 281-296

112 Sineva GS, Pospelov VA. Inhibition of GSK3beta enhances both adhesive and signalling activities of beta-catenin in mouse embryonic stem cells. Biol Cell 2010; 102: 549-560

113 Ko KH, Holmes T, Palladinetti P, Song E, Nordon R, O'Brien TA, Dolnikov A. GSK-3 $\beta$ inhibition promotes engraftment of ex vivo-expanded hematopoietic stem cells and modulates gene expression. Stem Cells 2011; 29: 108-118

114 Ogawa K, Nishinakamura R, Iwamatsu Y, Shimosato D, Niwa H. Synergistic action of Wnt and LIF in maintaining pluripotency of mouse ES cells. Biochem Biophys Res Commun 2006; 343: 159-166

115 Cartwright P, McLean C, Sheppard A, Rivett D, Jones K, Dalton S. LIF/ STAT3 controls ES cell self-renewal and pluripotency by a Myc-dependent mechanism. Development 2005; 132: 885-896

116 Holmes T, O'Brien TA, Knight R, Lindeman R, Shen S, Song E, Symonds $G$, Dolnikov A. Glycogen synthase kinase-3beta inhibition preserves hematopoietic stem cell activity and inhibits leukemic cell growth. Stem Cells 2008; 26: 1288-1297 
117 Jiang J, Zhao M, Zhang A, Yu M, Lin X, Wu M, Wang X, Lu H, Zhu S, Yu Y, Mao Z, Han W. Characterization of a GSK-3 inhibitor in culture of human cord blood primitive hematopoietic cells. Biomed Pharmacother 2010; 64: 482-486

118 Manceur AP, Tseng M, Holowacz T, Witterick I, Weksberg R, McCurdy $R D$, Warsh JJ, Audet J. Inhibition of glycogen synthase kinase-3 enhances the differentiation and reduces the proliferation of adult human olfactory epithelium neural precursors. Exp Cell Res 2011; 317: 2086-2098

119 Krause U, Harris S, Green A, Ylostalo J, Zeitouni S, Lee N, Gregory CA. Pharmaceutical modulation of canonical Wnt signaling in multipotent stromal cells for improved osteoinductive therapy. Proc Natl Acad Sci USA 2010; 107: 4147-4152

120 Wang FS, Ko JY, Weng LH, Yeh DW, Ke HJ, Wu SL. Inhibition of glycogen synthase kinase-3beta attenuates glucocorticoid-induced bone loss. Life Sci 2009; 85: 685-692

121 Gattinoni L, Zhong XS, Palmer DC, Ji Y, Hinricks CS, Yu Z, Wresinski C, Boni A, Cassard L, Garvin LM, Paulos CH, Muranski P, Restifo NP. Wnt signaling arrests effector $\mathrm{T}$ cell differentiation and generates CD8+ memory stem cells. Nat Med 2009; 15: 808-813

122 Zaragosi LE, Wdziekonski B, Fontaine C, Villageois P, Peraldi P, Dani C. Effects of GSK3 inhibitors on in vitro expansion and differentiation of human adipose-derived stem cells into adipocytes. BMC Cell Biol 2008; 9: 11

123 Lluis F, Pedone E, Pepe S, Cosma MP. Periodic activation of Wnt/betacatenin signaling enhances somatic cell reprogramming mediated by cell fusion. Cell Stem Cell 2008; 3: 493-507

124 Ullmann U, Gilles C, De Rycke M, Van de Velde H, Sermon K, Liebaers I. GSK-3-specific inhibitor-supplemented hESC medium prevents the epithelial-mesenchymal transition process and the up-regulation of matrix metalloproteinases in hESCs cultured in feeder-free conditions. Mol Hum Reprod 2008; 14: 169-179

125 Ikonomou L, Geras-Raaka E, Raaka BM, Gershengorn MC. $\beta$-catenin signaling in mesenchymal islet-derived precursor cells. Cell Prolif 2008; 41: 474-491

126 Umehara H, Kimura T, Ohtsuka S, Nakamura T, Kitajima K, Ikawa M, Okabe M, Niwa H, Nakano T. Efficient derivation of embryonic stem cells by inhibition of glycogen synthase kinase-3. Stem Cells 2007; 25: 2705-2711

127 Yang $W$, Wei W, Shi C, Zhu J, Ying W, Shen Y, Ye X, Fang L, Duo S, Che J, Shen $H$, Ding S, Deng $H$. Pluripotin combined with leukemia inhibitory factor greatly promotes the derivation of embryonic stem cell lines from refractory strains. Stem Cells 2009; 27: 383-389

128 Doungpunta J, Sathi A, Sathanawongs A, Jarujinda Y, Oranratnachai A. Fivefold increase in derivation rates of mouse embryonic stem cells after supplementation of the media with multiple factors. Theriogenology 2009; 72: 232-242

129 Wen J, Liu J, Song G, Liu L, Tang B, Li Z. Effects of 6-bromoindirubin-3'oxime on the maintenance of pluripotency of porcine embryonic germ cells in combination with stem cell factor, leukemia inhibitory factor and fibroblast growth factor. Reproduction 2010; 139: 10391046

130 Sato H, Amagai K, Shimizukawa R, Tamai Y. Stable generation of serum- and feeder-free embryonic stem cell-derived mice with full germline-competency by using a GSK3 specific inhibitor. Genesis 2009; 47: 414-422

131 Ribas J, Yuste VJ, Garrofé-Ochoa X, Meijer L, Esquerda JE, Boix J. 7-Bromoindirubin-3'-oxime uncovers a serine protease-mediated paradigm of necrotic cell death. Biochem Pharmacol 2008; 76: 39-52

132 Nam S, Buettner R, Turkson J, Kim D, Cheng JQ Muehlbeyer S, Hippe F, Vatter S, Merz KH, Eisenbrand G, Jove R. Indirubin derivatives inhibit Stat3 signaling and induce apoptosis in human cancer cells. Proc Natl Acad Sci USA 2005; 102: 5998-6003

133 Liu L, Nam S, Tian Y, Wu J, Wang Y, Scuto A, Polychronopoulos P, Magiatis $P$, Skaltsounis L, Jove R. 6-Bromoindirubin-3'-oxime inhibits JAK/ STAT3 signaling and induces apoptosis in human melanoma cells. Cancer Res 2011; 71: 3972-3979

134 Chebel A, Kagialis-Girard S, Catallo R, Chien WW, Mialou V, Domenech C, Badiou C, Tigaud I, Ffrench M. Indirubin derivatives inhibit malignant lymphoid cell proliferation. Leuk Lymphoma 2009; 50: 20492060

135 Song EY, Palladinetti P, Klamer G, Ko KH, Lindeman R, O'Brien TA, Dolnikov A. Glycogen synthase kinase- $3 \beta$ inhibitors suppress leukemia cell growth. Exp Hematol 2010; 38: 908-921 (e1)
136 Wang Z, Smith KS, Murphy M, Piloto O, Somervaille TC, Cleary ML. Glycogen synthase kinase 3 in MLL leukaemia maintenance and targeted therapy. Nature 2008; 455: 1205-1209

137 Williams SP, Nowicki MO, Liu F, Press R, Godlewski J, Abdel-Rasoul M, Kaur B, Fernandez SA, Chiocca EA, Lawler SE. Indirubins decrease glioma invasion by blocking migratory phenotypes in both the tumor and stromal endothelial cell compartments. Cancer Res 2011; 71: 53745380

138 Bilsland AE, Hoare S, Stevenson K, Plumb J, Gomez-Roman N, Cairney C, Burns S, Lafferty-White K, Roffey J, Hammonds T, Keith WN. Dynamic telomerase gene suppression via network effects of GSK3 inhibition. PLoS ONE 2009; 4: e6459

139 Cheng H, Woodgett J, Maamari M, Force T. Targeting GSK-3 family members in the heart: a very sharp double-edged sword. J Mol Cell Cardiol 2011; 51: 607-613

140 Tateishi K, Ashihara E, Honsho S, Takehara N, Nomura T, Takahashi T, Ueyama T, Yamagishi M, Yaku H, Matsubara H, Oh H. Human cardiac stem cells exhibit mesenchymal features and are maintained through Akt/GSK-3beta signaling. Biochem Biophys Res Commun 2007; 352: 635-641

141 Tseng AS, Engel FB, Keating MT. The GSK-3 inhibitor BIO promotes proliferation in mammalian cardiomyocytes. Chem Biol 2006; 13: 957963

142 Novoyatleva T, Diehl F, van Amerongen MJ, Patra C, Ferrazzi F, Bellazzi $R$ Engel FB. TWEAK is a positive regulator of cardiomyocyte proliferation. Cardiovasc Res 2010; 85: 681-690

143 Qyang Y, Martin-Puig S, Chiravuri M, Chen S, Xu H, Bu L, Jiang X, Lin L, Granger A, Moretti A, Caron L, Wu X, Clarke J, Taketo MM, Laugwitz KL, Moon RT, Gruber P, Evans SM, Ding S, Chien KR. The renewal and differentiation of Isl1+ cardiovascular progenitors are controlled by a Wnt/ beta-catenin pathway. Cell Stem Cell 2007; 1: 165-179

144 Bu L, Jiang X, Martin-Puig S, Caron L, Zhu S, Shao Y, Roberts DJ, Huang PL, Domian IJ, Chien KR. Human ISL1 heart progenitors generate diverse multipotent cardiovascular cell lineages. Nature 2009; 460: $113-117$

145 Valerio A, Bertolotti P, Delbarba A, Perego C, Dossena M, Ragni M, Spano $P$, Carruba MO, De Simoni MG, Nisoli E. Glycogen synthase kinase-3 inhibition reduces ischemic cerebral damage, restores impaired mitochondrial biogenesis and prevents ROS production. J Neurochem 2011; 116: 1148-1159

146 Skardelly M, Gaber K, Schwarz J, Milosevic J. Neuroprotective effects of the beta-catenin stabilization in an oxygen- and glucose-deprived human neural progenitor cell culture system. Int J Dev Neurosci 2011; 29: $543-547$

147 Barillas R, Friehs I, Cao-Danh H, Martinez JF, del Nido PJ. Inhibition of glycogen synthase kinase - $3 \beta$ improves tolerance to ischemia in hypertrophied hearts. Ann Thorac Surg 2007; 84: 126-133

148 Trivedi CM, Luo Y, Yin Z, Zhang M, Zhu W, Wang T, Floss T, Goettlicher M, Noppinger PR, Wurst W, Ferrari VA, Abrams CS, Gruber PJ, Epstein JA. Hdac2 regulates the cardiac hypertrophic response by modulating Gsk3 beta activity. Nat Med 2007; 13: 324-331

149 Lin CL, Wang JY, Huang YT, Kuo YH, Surendran K, Wang FS. Wnt/betacatenin signaling modulates survival of high glucose-stressed mesangial cells. J Am Soc Nephrol 2006; 17: 2812-2820

150 Kuure S, Popsueva A, Jakobson M, Sainio K, Sariola H. Glycogen synthase kinase- 3 inactivation and stabilization of beta-catenin induce nephron differentiation in isolated mouse and rat kidney mesenchymes. J Am Soc Nephrol 2007; 18: 1130-1139

151 Wang Y, Huang WC, Wang CY, Tsai CC, Chen CL, Chang YT, Kai JI, Lin CF. Inhibiting glycogen synthase kinase-3 reduces endotoxaemic acute renal failure by down-regulating inflammation and renal cell apoptosis. Br J Pharmacol 2009; 157: 1004-1013

152 Mussmann R, Geese M, Harder F, Kegel S, Andag U, Lomow A, Burk U, Onichtchouk D, Dohrmann C, Austen M. Inhibition of GSK3 promotes replication and survival of pancreatic beta cells. J Biol Chem 2007; 282: 12030-12037

153 Itoh T, Kamiya Y, Okabe M, Tanaka M, Miyajima A. Inducible expression of Wnt genes during adult hepatic stem/progenitor cell response. FEBS Lett 2009; 583: 777-781

154 Meijer L, Flajolet M, Greengard P. Pharmacological inhibitors of glycogen synthase kinase 3. Trends Pharmacol Sci 2004; 25: 471-480

155 Lim YW, Yoon SY, Choi JE, Kim SM, Lee HS, Choe H, Lee SC, Kim DH. Maintained activity of glycogen synthase kinase-3beta despite of its phosphorylation at serine-9 in okadaic acid-induced neurodegenerative model. Biochem Biophys Res Commun 2010; 395: 207-212 
156 Martin L, Magnaudeix A, Esclaire F, Yardin C, Terro F. Inhibition of glycogen synthase kinase-3beta downregulates total tau proteins in cultured neurons and its reversal by the blockade of protein phosphatase-2A. Brain Res 2009; 1252: 66-75

157 Martin L, Page G, Terro F. Tau phosphorylation and neuronal apoptosis induced by the blockade of PP2A preferentially involve GSK3 $\beta$. Neurochem Int 2011; 59: 235-250

158 Martin L, Magnaudeix A, Wilson CM, Yardin C, Terro F. The new indirubin derivative inhibitors of glycogen synthase kinase-3, 6-BIDECO and 6-BIMYEO, prevent tau phosphorylation and apoptosis induced by the inhibition of protein phosphatase-2A by okadaic acid in cultured neurons. J Neurosci Res 2011; 89: 1802-1811

159 Hongisto V, Smeds N, Brecht S, Herdegen T, Courtney MJ, Coffey ET. Lithium blocks the c-Jun stress response and protects neurons via its action on glycogen synthase kinase 3. Mol Cell Biol 2003; 23: 60276036

160 Nguyen TB, Lucero GR, Chana G, Hult BJ, Tatro ET, Masliah E, Grant I, Achim CL, Everall IP; HIV Neurobehavioral Research Group. Glycogen synthase kinase-3beta (GSK-3beta) inhibitors AR-A014418 and B6B30 prevent human immunodeficiency virus-mediated neurotoxicity in primary human neurons. J Neurovirol 2009; 15: 434-438

161 Meares GP, Mines MA, Beurel E, Eom TY, Song L, Zmijewska AA, Jope RS. Glycogen synthase kinase-3 regulates endoplasmic reticulum (ER) stress-induced CHOP expression in neuronal cells. Exp Cell Res 2011; 317: 1621-1628

162 Magiatis P, Polychronopoulos P, Skaltsounis AL, Lozach O, Meijer L, Miller $D B, O$ 'Callaghan JP. Indirubins deplete striatal monoamines in the Intact and MPTP-treated mouse brain and block kainate-induced striatal astrogliosis. Neurotoxicol Teratol 2010; 32: 212-219

163 Kim WY, Zhou FQ Zhou J, Yokota Y, Wang YM, Yoshimura T, Kaibuchi K, Woodgett JR, Anton ES, Snider WD. Essential roles for GSK-3s and GSK-3-primed substrates in neurotrophin induced and hippocampal axon growth. Neuron 2006; 52: 981-996

164 Alabed YZ, Pool M, Ong Tone S, Sutherland C, Fournier AE. GSK-3ß regulates myelin - dependent axon outgrowth inhibition through CRMP4. J Neurosci 2010; 30: 5635-5643

165 Xingi E, Smirlis D, Myrianthopoulos V, Magiatis P, Grant KM, Meijer L, Mikros E, Skaltsounis AL, Soteriadou K. 6-Br-5methylindirubin-3'oxime (5-Me-6-BIO) targeting the leishmanial glycogen synthase kinase-3 (GSK-3) short form affects cell-cycle progression and induces apoptosis-like death: exploitation of GSK-3 for treating leishmaniasis. Int J Parasitol 2009; 39: 1289-1303
166 Grant KM, Dunion MH, Yardley V, Skaltsounis AL, Marko D, Eisenbrand G, Croft SL, Meijer L, Mottram JC. Inhibitors of Leishmania mexicana CRK3 cyclin-dependent kinase: chemical library screen and antileishmanial activity. Antimicrob Agents Chemother 2004; 48: 3033-3042

167 Mahendra A, Vivek K, Parameswaran S, Mohan CG. Homology modeling and atomic level binding study of Leishmania MAPK with inhibitors. J Mol Model 2010; 16: 475-488

168 Krivogorsky B, Grundt P, Yolken R, Jones-Brando L. Inhibition of Toxoplasma gondii by indirubin and tryptanthrin analogs. Antimicrob Agents Chemother 2008; 52: 4466-4469

169 Fabres A, de Andrade CP, Guizzo M, Sorgine MHF, de 0 Paiva-Silva G, Masuda A, da Silva Vaz I, Logullo C. Effect of GSK-3 activity, enzymatic inhibition and gene silencing by RNAi on tick oviposition and egg hatching. Parasitology 2010; 137; 1-10

170 Pohjanvirta R, Tuomisto J. Short-term toxicity of 2,3,7,8-tetrachlorodibenzo-p-dioxin in laboratory animals: effects, mechanisms, and animal models. Pharmacol Rev 1994; 46: 483-549

171 Sugihara K, Okayama T, Kitamura S, Yamashita K, Yasuda M, Miyairi S, Minobe Y, Ohta S. Comparative study of aryl hydrocarbon receptor ligand activities of six chemicals in vitro and in vivo. Arch Toxicol 2008; 82: $5-11$

172 Peter Guengerich F, Martin MV, McCormick WA, Nguyen LP, Glover E, Bradfield CA. Aryl hydrocarbon receptor response to indigoids in vitro and in vivo. Arch Biochem Biophys 2004; 423: 309-316

173 Adachi J, Mori Y, Matsui S, Matsuda T. Comparison of gene expression patterns between 2,3,7,8-tetrachlorodibenzo-p-dioxin and a natural arylhydrocarbon receptor ligand, indirubin. Toxicol Sci 2004; 80: 161-169

174 Schlezinger JJ, Liu D, Farago M, Seldin DC, Belguise K, Sonenshein GE, Sherr $D H$. A role for the aryl hydrocarbon receptor in mammary gland tumorigenesis. Biol Chem 2006; 387: 1175-1187

175 Puga A, Barnes SJ, Dalton TP, Chang C, Knudsen ES, Maier MA. Aromatic hydrocarbon receptor interaction with the retinoblastoma protein potentiates repression of E2F-dependent transcription and cell cycle arrest. J Biol Chem 2000; 275: 2943-2950

176 Korzeniewski N, Wheeler S, Chatterjee P, Duensing A, Duensing S. A novel role of the aryl hydrocarbon receptor (AhR) in centrosome amplification - implications for chemoprevention. Mol Cancer 2010; 9: 153 